\title{
SYNTHESIS AND CHARACTERIZATION OF BINUCLEAR TANTALUM HYDRIDE COMPLEXES*
}

\author{
A. J. SCIOLY, M. L. LUETKENS, Jr†, and R. B. WILSON, JR \\ Department of Chemistry, The University of Michigan, Ann Arbor, MI 48109, U.S.A.
}

\section{J. C. HUFFMAN}

Molecular Structure Center, Indiana University, Bloomington, IN 47405, U.S.A.

and

\section{A. P. SATTELBERGER}

Inorganic and Structural Chemistry Group (INC-4), Los Alamos National Laboratory, Los Alamos, NM 87545, U.S.A.

(Received 19 November 1986)

\begin{abstract}
Reduction of the quadruply-bridged $(2 \mathrm{Cl}, 2 \mathrm{H})$ tantalum(IV) dimer, $\mathrm{Ta}_{2} \mathrm{Cl}_{6}$ $\left(\mathrm{PMe}_{3}\right)_{4} \mathrm{H}_{2}$ (2) with sodium amalgam in glyme or THF at $0^{\circ} \mathrm{C}$ provides deep green $\mathrm{Ta}_{2} \mathrm{Cl}_{4}\left(\mathrm{PMe}_{3}\right)_{4} \mathrm{H}_{2}(3)$ in $70 \%$ yield. Dimer 3 has a $D_{2 d} \mathrm{Ta}_{2} \mathrm{Cl}_{4}\left(\mathrm{PMe}_{3}\right)_{4}$ substructure which closely resembles that of the quadruply metal-metal-bonded dimer $\mathrm{W}_{2} \mathrm{Cl}_{4}\left(\mathrm{PMe}_{3}\right)_{4}$. The hydride ligands of 3 are located on a diagonal plane, bridging the two tantalum atoms and the Ta-Ta separation is $2.545(1) \AA$. 3 reacts cleanly with $\mathrm{Cl}_{2}, \mathrm{HCl}$ and $\mathrm{H}_{2}$ in diethyl ether to provide the quadruply-bridged dimers $2, \mathrm{Ta}_{2} \mathrm{Cl}_{5}\left(\mathrm{PMe}_{3}\right)_{4} \mathrm{H}_{3}$ (4), and $\mathrm{Ta}_{2} \mathrm{Cl}_{4}\left(\mathrm{PMe}_{3}\right)_{4} \mathrm{H}_{4}(5)$, respectively, in high yield. Dimer 5 can also be prepared in high yield via thermolysis of the tantalum(IV) hydride $\mathrm{TaCl}_{2} \mathrm{H}_{2}\left(\mathrm{PMe}_{3}\right)_{4}$ (6) in refluxing methylcyclohexane. The X-ray structure of 5 shows that the $(\mu-\mathrm{H})_{4}$ group is staggered by $45^{\circ}$ with respect to the eclipsed pyramidal $\mathrm{TaCl}_{2}\left(\mathrm{PMe}_{3}\right)_{2}$ end groups. The molecular symmetry of 5 is $D_{2 d}$ and the Ta-Ta separation is $2.511(2) \AA$. Multiple-scattering $\mathrm{X}_{\alpha}$ calculations on the model compounds $\mathrm{Ta}_{2} \mathrm{Cl}_{4}\left(\mathrm{PH}_{3}\right)_{4} \mathrm{H}_{2}$ and $\mathrm{Ta}_{2} \mathrm{Cl}_{4}\left(\mathrm{PH}_{3}\right)_{4}$ are used to elucidate the ground-state electronic structures of 3 and 5 , and to probe the question of $(\mu-\mathrm{H})_{x}$ rotation about the metal-metal bonds in these complexes. Crystal data (at $\left.160^{\circ} \mathrm{C}\right)$ are as follows: for 3 , monoclinic space group $C 2 / c, a=18.371(5) \AA, b=9.520(3) \AA$, $c=18.942(6) \AA, \beta=125.36(2)^{\circ}, V=2701.8 \AA^{3}, Z=4, d_{\text {calc. }}=1.991 \mathrm{~g} \mathrm{~cm}^{-3}$; for 5 , tetragonal space group $P 4 / \mathrm{nbm}, \quad a=b=12.579(2) \AA, \quad c=10.205(2) \AA, \quad V=1614.7 \AA^{3}, \quad Z=2$, $d_{\text {calc. }}=1.670 \mathrm{~g} \mathrm{~cm}^{-3}$.
\end{abstract}

The great propensity with which molybdenum and tungsten form metal-metal-bonded dinuclear complexes $^{2}$ might lead one to expect the same of their group 5 neighbors, niobium and tantalum. Operating under this assumption, we set out, several years ago, to prepare a number of low-valent

* Metal-metal bonded complexes of the early transition metals-XI. For Part X, see Ref. 1.

†Dow Britton Fellow (1983-1984).

$\ddagger$ Author to whom correspondence should be addressed. ditantalum complexes. Our choice of target molecules was influenced by a report ${ }^{3}$ on the syntheses of $\mathrm{W}_{2} \mathrm{Cl}_{6}\left(\mathrm{PMe}_{3}\right)_{4}$ and $\mathrm{W}_{2} \mathrm{Cl}_{4}\left(\mathrm{PMe}_{3}\right)_{4}$. These dimers were obtained by sodium amalgam reduction of polymeric tungsten(IV) chloride in THF, in the presence of trimethylphosphine $\left(\mathrm{PMe}_{3}\right)$, and we reasoned that their tantalum(III) and tantalum(II) analogues could be prepared in a similar fashion. This logic held up in the case of $\mathrm{Ta}_{2} \mathrm{Cl}_{6}\left(\mathrm{PMe}_{3}\right)_{4}$ (1). Reduction of tantalum(V) chloride with sodium amalgam ( 2 equivalents) in toluene- $\mathrm{PMe}_{3}$ provides burgundy red 1 in good yield. ${ }^{4}$ The latter adopts 
an edge-sharing bioctahedral geometry with axial phosphines on one metal center and equatorial phosphines on the second, and it contains a formal Ta-Ta double bond, represented by a $\sigma^{2} \pi^{2}$ groundstate electronic configuration. The synthesis of $\mathrm{Ta}_{2} \mathrm{Cl}_{4}\left(\mathrm{PMe}_{3}\right)_{4}$, a molecule which should contain an unbridged Ta-Ta triple bond $\left(\sigma^{2} \pi^{4}\right)$, has not been achieved. Treatment of 1 with a variety of powerful reducing agents (e.g. $\mathrm{NaNp}$ and $\mathrm{Na}-\mathrm{K}$ ) failed to effect its conversion to the desired product. This disappointing result was offset by our observation that the $\mathrm{Ta}=\mathrm{Ta}$ bond in 1 could be hydrogenated under mild conditions $\left(25^{\circ} \mathrm{C}, 1 \mathrm{~atm} \mathrm{H}_{2}\right) .^{5}$ The hydrogenation product, viz. $\mathrm{Ta}_{2} \mathrm{Cl}_{6}\left(\mathrm{PMe}_{3}\right)_{4} \mathrm{H}_{2}$ (2) is a quadruply-bridged $(2 \mathrm{Cl}, 2 \mathrm{H})$ dimer with pyramidal $\mathrm{TaCl}_{2}\left(\mathrm{PMe}_{3}\right)_{2}$ end groups. Subsequently, we discovered that 2 could be reduced to $\mathrm{Ta}_{2} \mathrm{Cl}_{4}(\mathrm{P}$ $\left.\mathrm{Me}_{3}\right)_{4} \mathrm{H}_{2}$ (3), a doubly hydrogen-bridged tantalum(III) dimer, which may be viewed as the hydrogenation product of the elusive $\mathrm{Ta}_{2} \mathrm{Cl}_{4}\left(\mathrm{PMe}_{3}\right)_{4}$. In this paper, we describe: (1) the synthesis, physicochemical properties and $\mathrm{X}$-ray structure of 3; (2) the reactions of 3 with $\mathrm{Cl}_{2}, \mathrm{HCl}$ and $\mathrm{H}_{2} ;$; (3) the X-ray structure of the hydrogenation product, $\mathrm{Ta}_{2} \mathrm{Cl}_{4}\left(\mathrm{PMe}_{3}\right)_{4} \mathrm{H}_{4}$, a molecule with four bridging hydrides; and (4) the electronic structures of 3 and $\mathrm{Ta}_{2} \mathrm{Cl}_{4}\left(\mathrm{PMe}_{3}\right)_{4} \mathrm{H}_{4}$. Preliminary reports of certain aspects of this work have been published. ${ }^{6,7}$

\section{RESULTS}

\section{Synthesis and characterization of 3}

Reduction of 2 with 2 equivalents of sodium amalgam in ethylene glycol dimethyl ether (glyme) or THF [eqn(1)]:

$$
\begin{gathered}
\mathrm{Ta}_{2} \mathrm{Cl}_{6}\left(\mathrm{PMe}_{3}\right)_{4} \mathrm{H}_{2}+2 \mathrm{Na}-\mathrm{Hg} \\
2 \\
\underset{4 \mathrm{~h}, 0^{\circ} \mathrm{C}}{\mathrm{THF}} \mathrm{Ta}_{2} \mathrm{Cl}_{4}\left(\mathrm{PMe}_{3}\right)_{4} \mathrm{H}_{2}+2 \mathrm{NaCl} \\
3
\end{gathered}
$$

at $0^{\circ} \mathrm{C}$ provides deep green solutions containing 3 . The latter is isolated as a dark green powder after filtration, solvent removal, extraction of the solid residue with diethyl ether, filtration, and evaporation of the filtrate. These operations provide a spectroscopically pure product in $\mathrm{ca} 70 \%$ yield. If only 1 equivalent of sodium amalgam is used, an approximately $1: 1$ mixture of 2 and 3 is obtained. There is no spectroscopic evidence (NMR or ESR) for the presumed intermediate in the reduction, $\mathrm{Ta}_{2} \mathrm{Cl}_{5}\left(\mathrm{PMe}_{3}\right)_{4} \mathrm{H}_{2}$.

Dimer 3 is very air-sensitive in the solid state, decomposing within seconds after exposure to laboratory air. It is soluble in ethereal and aromatic solvents, and slightly soluble in hexane. 3 decomposes rapidly in chloroform, methylene chloride and acetonitrile. Well-defined products were not obtained from these reactions. The dimeric formulation was established by an osmometric molecular weight measurement in benzene (Calc: 810 ; Found: 813). Attempts to obtain electron impact or chemical ionization mass spectra were unsuccessful. $\mathrm{PMe}_{3}$ was the only gas-phase species observed.

The presence, number and location of the hydride ligands were established by NMR and IR techniques. The room-temperature $360-\mathrm{MHz}$ proton NMR spectrum of 3 is shown in Fig. 1. The binomial quintet $\left({ }^{2} J_{\mathrm{PH}}=13.4 \mathrm{~Hz}\right)$ at $\delta 8.52$ (area 2) is assigned to a pair of chemically and magnetically equivalent bridging hydride ligands. The resonance at $\delta 1.52$ (area 36) is due to the methyl hydrogens of virtually coupled pseudo-trans $\mathrm{PMe}_{3}$ ligands. The ${ }^{31} \mathbf{P}-\left\{{ }^{1} \mathrm{H}\right\}$ NMR spectrum consists of a single resonance at $\delta+1.3$ which splits into a 1:2:1 triplet $\left({ }^{2} J_{\mathrm{PH}}=13.4 \mathrm{~Hz}\right)$ upon selective ${ }^{1} \mathrm{H}$-decoupling of the proton NMR resonance at $\delta 1.52$. No significant changes were observed in either the ${ }^{1} \mathrm{H}$ or ${ }^{31} \mathrm{P}$ NMR spectra on cooling toluene- $d_{8}$ solutions of 3 to $-90^{\circ} \mathrm{C}$.

The location of the hydride ligands in bridging positions is supported by the IR spectra ( $\mathrm{KBr}$ disc) of $\mathrm{Ta}_{2} \mathrm{Cl}_{4}\left(\mathrm{PMe}_{3}\right)_{4} \mathrm{H}_{2}$ and $\mathrm{Ta}_{2} \mathrm{Cl}_{4}\left(\mathrm{PMe}_{3}\right)_{4} \mathrm{D}_{2}$. The former shows a band of moderate intensity at $1232 \mathrm{~cm}^{-1}$ which shifts to $860 \mathrm{~cm}^{-1}$ in the spectrum of the deuteride $\left(v_{\mathrm{H}} / v_{\mathrm{D}}=1.43\right)$. We assign these bands as the $\mathrm{Ta}-\mathrm{H}(\mathrm{D})-\mathrm{Ta}$ vibrations.

With the preceding data in hand, we initially assumed that 3 was an edge-sharing bioctahedral complex with $C_{2 h}$-symmetry. Such a structure is reminiscent of those found ${ }^{8,9}$ for $\mathrm{H}_{2} \mathrm{~W}_{2}(\mathrm{CO})_{8}^{2-}$ and $\mathrm{H}_{2} \operatorname{Re}_{2}(\mathrm{CO})_{8}$ but it was rejected on steric grounds. In 1, which has axial phosphines on one metal center and equatorial phosphines on the second, there is clear structural evidence for axial crowding, i.e. the axial ligands are bent back and the $\mathrm{TaCl}_{2}\left(\mathrm{PMe}_{3}\right)_{2}$ end groups twist away from each other. ${ }^{4}$ Placing four phosphines in axial positions and (presumably) shortening the metal-metal bond $(1 \rightarrow 3)$ will certainly exacerbate the axial crowding problem. Space-filling molecular models show this quite clearly. The rejection of the $C_{2 h}$ structure, the only static model which satisfies the spectroscopic data, raised the obvious question and we turned to $\mathrm{X}$-ray crystallography for the answer.

\section{Solid state structure of 3}

In the crystalline state, the compound is composed of discrete molecules of 3. Final atomic coordinates and isotropic thermal parameters are 


\section{$\left[\mathrm{TaCl}_{2}\left(\mathrm{PMe}_{3}\right)_{2}\right]_{2}(\mu-\mathrm{H})_{2}$}

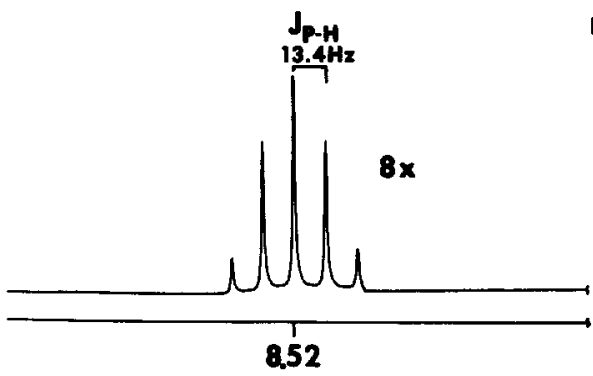

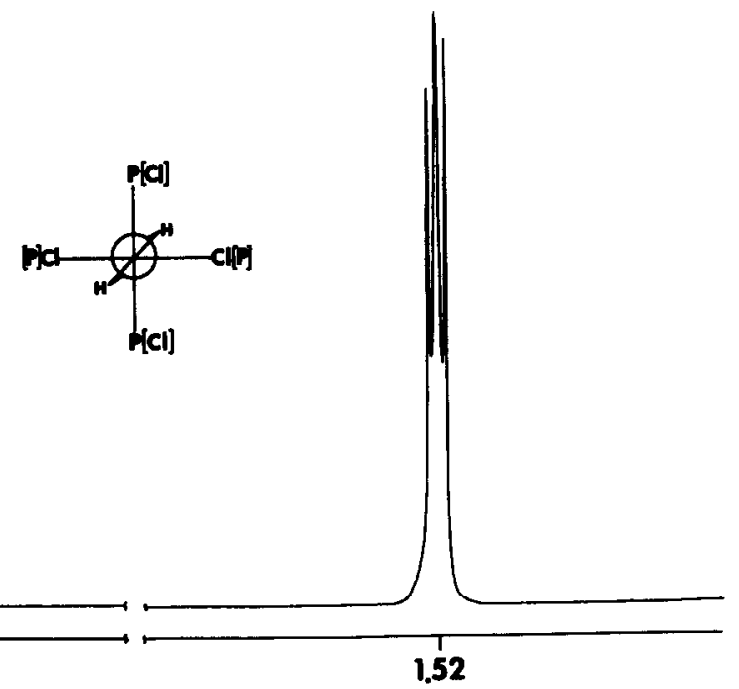

Fig. 1. 360-MHz ${ }^{1} \mathrm{H}$ NMR spectrum of $\mathrm{Ta}_{2} \mathrm{Cl}_{4}\left(\mathrm{PMe}_{3}\right)_{4} \mathrm{H}_{2}$. In this and the following proton NMR spectra, end-on Newman projections are included and the atoms in brackets ([ ]) are associated with the back tantalum.

Table 1. Fractional coordinates and isotropic thermal parameters for $\mathrm{Ta}_{2} \mathrm{Cl}_{4}\left(\mathrm{PMe}_{3}\right)_{4} \mathrm{H}_{2}{ }^{a}$

\begin{tabular}{lllll}
\hline Atom & $x$ & $y$ & $z$ & $B_{\text {iso }}$ \\
\hline $\mathrm{Ta}(1)$ & $10000^{*}$ & $3890(1)$ & $2500^{*}$ & 10 \\
$\mathrm{Ta}(2)$ & $10000^{*}$ & $6564(1)$ & $2500^{*}$ & 10 \\
$\mathrm{Cl}(3)$ & $9743(2)$ & $2778(3)$ & $1227(2)$ & 19 \\
$\mathrm{P}(4)$ & $8338(2)$ & $3323(3)$ & $1816(2)$ & 18 \\
$\mathrm{P}(5)$ & $9720(2)$ & $7129(3)$ & $1019(2)$ & 18 \\
$\mathrm{Cl}(6)$ & $8566(2)$ & $7645(3)$ & $1899(2)$ & 19 \\
$\mathrm{C}(7)$ & $7551(9)$ & $3978(15)$ & $747(9)$ & 31 \\
$\mathrm{C}(8)$ & $8122(10)$ & $1453(13)$ & $1708(11)$ & 28 \\
$\mathrm{C}(9)$ & $7863(10)$ & $3917(17)$ & $2388(11)$ & 33 \\
$\mathrm{C}(10)$ & $550(9)$ & $6458(15)$ & $879(9)$ & 22 \\
$\mathrm{C}(11)$ & $9737(16)$ & $9005(15)$ & $836(12)$ & 37 \\
$\mathrm{C}(12)$ & $8676(11)$ & $6512(18)$ & $72(10)$ & 32 \\
\hline
\end{tabular}

${ }^{a}$ Fractional coordinates are $\times 10^{4}$ for nonhydrogen atoms and $\times 10^{3}$ for hydrogen atoms. $B_{\text {iso }}$ values are $\times 10$. Isotropic values for those atoms refined anisotropically were calculated using the formula given in: W. C. Hamilton, Acta Cryst. 1959, 12, 609. Parameters marked with an asterisk $\left({ }^{*}\right)$ were not varied.

listed in Table 1. Interatomic distances and angles are provided in Table 2 . An ORTEP drawing of 3, indicating the atom-numbering scheme, is shown in Fig. 2. A two-fold axis, passing through $\mathrm{Ta}(1)$ and $\mathrm{Ta}(2)$ is required by the space group.

The structure of 3 , excluding the bridging hydrides (vide infra), resembles those of the quadruply metal-metal-bonded group 6 dimers $\mathrm{Mo}_{2} \mathrm{Cl}_{4}\left(\mathrm{PMe}_{3}\right)_{4}$ and $\mathrm{W}_{2} \mathrm{Cl}_{4}\left(\mathrm{PMe}_{3}\right)_{4} \cdot{ }^{10}$ The latter also have eclipsed pyramidal $\mathrm{MCl}_{2}\left(\mathrm{PMe}_{3}\right)_{2}$ end groups and staggered $\mathrm{PMe}_{3}$ ligands. In 3 , the $\mathrm{Ta}-$ $\mathrm{Ta}-\mathrm{Cl}$ and $\mathrm{Ta}-\mathrm{Ta}-\mathrm{P}$ angles average $115.7[3]$ and $102.0[1]^{\circ}$, respectively.* Corresponding values in $\mathrm{W}_{2} \mathrm{Cl}_{4}\left(\mathrm{PMe}_{3}\right)_{4}$ are $111.65[9]$ and $101.14[4]^{\circ}$. The $\mathrm{Ta}-\mathrm{Cl}$ and $\mathrm{Ta}-\mathrm{P}$ bond lengths average $2.416[2]$ and $2.596[4] \AA$, respectively. These bond distances are comparable to those found for the axial ligands in 1 . The $\mathrm{Ta}=\mathrm{Ta}$ bond length of $2.545(1) \AA$ is, by a wide margin, the shortest metal-metal double bond yet observed in diniobium or ditantalum chemistry, and it compares favorably with the $\mathrm{W}=\mathrm{W}$ bond length of $2.530(2) \AA$ found in the isoelectronic tungsten(IV) dimer $\mathrm{W}_{2} \mathrm{~S}_{2}\left(\mathrm{~S}_{2} \mathrm{CNEt}_{2}\right)_{4} \cdot{ }^{11}$

The next feature of 3 to consider is the bridge region. There are two conceivable locations for the hydride ligands, i.e. they are either eclipsed or staggered with respect to the terminal ligands. Our prejudice for the $D_{2}$ structure (Fig. 2) is clear but it requires some justification. A careful search of the final difference Fourier map revealed only one peak $\left(\sim 0.8 e \AA^{-3}\right.$ ) which might reasonably be assigned as $\mathrm{H}_{\mathrm{b}}$. It was located on the diagonal plane $1.97 \AA$ from $\mathrm{Ta}(1)$ and $1.86 \AA$ from $\mathrm{Ta}(2)$, and the $\mathrm{Ta}-\mathrm{H}_{\mathrm{b}}-$ Ta angle was $83.1^{\circ}$. The shortest intramolecular contact was $\mathrm{H}_{\mathrm{b}}-\mathrm{P}(5)$ at $2.54 \AA$. When the position of $\mathrm{H}_{\mathrm{b}}$ was rotated $45^{\circ}$ into the eclipsed $C_{2 v}$-conformation, this contact distance shortened to $2.02 \AA$. These observations favor the $D_{2}$ structure but there

*The number in brackets is equal to $\left[\Sigma_{m} \Lambda_{i}^{2} / m(m-\right.$ 1) $]^{1 / 2}$, where $\Delta_{i}$ is the deviation of the ith value in a set of $m$ such values from the arithmetic mean. 


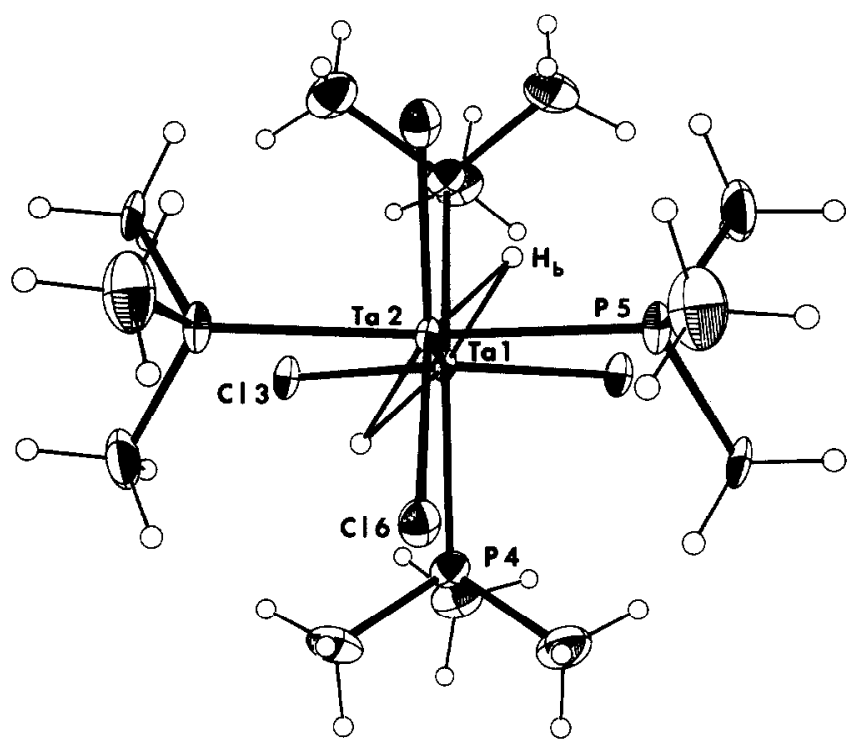

Fig. 2. ORTEP drawing of $\mathrm{Ta}_{2} \mathrm{Cl}_{4}\left(\mathrm{PMe}_{3}\right)_{4} \mathrm{H}_{2}$. Each nonhydrogen atom is represented by a thermal vibration ellipsoid enclosing $50 \%$ of its electron density. A crystallographic $C_{2}$-axis runs through $\mathrm{Ta}(1)$ and $\operatorname{Ta}(2)$.

are some complications. These can be summarized as follows. (1) Because of experimental difficulties (see Experimental), the X-ray data were not corrected for absorption $\left[\mu=86.32 \mathrm{~cm}^{-1},\left(\mathrm{Mo}^{-\mathrm{K}_{\alpha}}\right)\right]$. (2) As a consequence of (1), the final difference map was not as "clean" as one would like. Several peaks of comparable or greater density than $\mathrm{H}_{b}$ were observed near the tantalum $\left(1.5-2.1 e \AA^{-3}\right)$, phosphorus $\left(<0.8 e \AA^{-3}\right)$ and chlorine $\left(<0.8 e \AA^{-3}\right)$ atoms. (3) There are no significant distortions in the $\mathrm{Ta}_{2} \mathrm{Cl}_{4}\left(\mathrm{PMe}_{3}\right)_{4}$ portion of the molecule (Table 2 and supplementary data $\dagger$ ) which might be used as corroborating evidence for the location of $\mathbf{H}_{b}$. In fact, given the number of possible hydride sites, one must accept the possibility that the bridging hydrides are disordered in the solid state. In view of these reservations, $\mathrm{H}_{b}$ was not included in the final stages of refinement.

A static $D_{2}$ structure cannot account for the proton NMR spectrum shown in Fig. 1 unless the two $\mathrm{P}-\mathrm{H}$ coupling constants are accidentally degenerate. An alternative explanation for the apparent magnetic equivalence of $H_{b}(1)$ and $H_{b}(2)$, and the one which we favor, is rapid rotation of

†Tables of anisotropic thermal parameters and observed and calculated structure factors for $\mathbf{3}$ and $\mathbf{5}$, plus hydrogen atom positions and tortion angles for 3 are available from the Executive Editor, Queen Mary College, London, or the Indiana University Molecular Structure Center, upon request. the bridging ligands about the $\mathrm{Ta}-\mathrm{Ta}$ axis in solution. We will return to this point later on in the paper.

\section{Reactivity of 3}

3 is very susceptible to binuclear oxidativeaddition reactions. Here we describe three representative examples.

(1) Ether solutions of 3 react readily with chlorine at $-20^{\circ} \mathrm{C}$ [eqn (2)]:

$$
\begin{aligned}
& \mathrm{Ta}_{2} \mathrm{Cl}_{4}\left(\mathrm{PMe}_{3}\right)_{4} \mathrm{H}_{2}+\mathrm{Cl}_{2} \\
& 3 \\
& \underset{1 \mathrm{~h}, \underset{-20^{\circ} \mathrm{C}}{\mathrm{OEt}_{2}} \mathrm{Ta}_{2} \mathrm{Cl}_{6}\left(\mathrm{PMe}_{3}\right)_{4} \mathrm{H}_{2}}{2}
\end{aligned}
$$

and deposit a sparingly soluble green powder in $70 \%$ yield. The latter has been identified as 2 by comparison of its ${ }^{1} \mathrm{H}$ NMR spectrum [Fig. 3(a)] with that of an authentic sample ${ }^{5}$ prepared by the original route (vide supra). As an aside, we note that there are two isomers of 2 (one with $C_{s}$ symmetry and one with $D_{2}$-symmetry) depending on the disposition of the bridging ligands. In our studies, only the $C_{\mathrm{s}}$ isomer has been detected and it does not rearrange to the $D_{2}$ isomer thermally or photochemically. 
Table 2. Selected bond distances $(\AA)$ and angles $\left({ }^{\circ}\right)$ for $\mathrm{Ta}_{2} \mathrm{Cl}_{4}\left(\mathrm{PMe}_{3}\right)_{4} \mathrm{H}_{2}$

\begin{tabular}{llllllr}
\hline \multicolumn{1}{c}{ A } & \multicolumn{1}{c}{ B } & Distance & \multicolumn{1}{c}{ A } & \multicolumn{1}{c}{ B } & \multicolumn{1}{c}{ C } & Angle \\
\hline $\mathrm{Ta}(1)$ & $\mathrm{Ta}(2)$ & $2.545(1)$ & $\mathrm{Ta}(2)$ & $\mathrm{Ta}(1)$ & $\mathrm{Cl}(3)$ & $116.0(1)$ \\
$\mathrm{Ta}(1)$ & $\mathrm{Cl}(3)$ & $2.418(3)$ & $\mathrm{Ta}(2)$ & $\mathrm{Ta}(1)$ & $\mathrm{P}(4)$ & $102.0(1)$ \\
$\mathrm{Ta}(1)$ & $\mathrm{P}(4)$ & $2.591(3)$ & $\mathrm{Cl}(3)$ & $\mathrm{Ta}(1)$ & $\mathrm{Cl}(3)^{\prime}$ & $128.1(1)$ \\
$\mathrm{Ta}(2)$ & $\mathrm{Cl}(6)$ & $2.413(3)$ & $\mathrm{Cl}(3)$ & $\mathrm{Ta}(1)$ & $\mathrm{P}(4)^{\prime}$ & $85.2(1)$ \\
$\mathrm{Ta}(2)$ & $\mathrm{P}(5)$ & $2.600(3)$ & $\mathrm{P}(4)$ & $\mathrm{Ta}(1)$ & $\mathrm{P}(4)^{\prime}$ & $155.9(1)$ \\
$\mathrm{P}(4)$ & $\mathrm{C}(7)$ & $1.785(14)$ & $\mathrm{Ta}(1)$ & $\mathrm{Ta}(2)$ & $\mathrm{Cl}(6)$ & $115.3(1)$ \\
$\mathrm{P}(4)$ & $\mathrm{C}(8)$ & $1.810(12)$ & $\mathrm{Ta}(1)$ & $\mathrm{Ta}(2)$ & $\mathrm{P}(5)$ & $102.0(1)$ \\
$\mathrm{P}(4)$ & $\mathrm{C}(9)$ & $1.831(15)$ & $\mathrm{Cl}(6)$ & $\mathrm{Ta}(2)$ & $\mathrm{Cl}(6)^{\prime}$ & $129.5(1)$ \\
$\mathrm{P}(5)$ & $\mathrm{C}(10)$ & $1.807(13)$ & $\mathrm{Cl}(6)$ & $\mathrm{Ta}(2)$ & $\mathrm{P}(5)$ & $85.6(1)$ \\
$\mathrm{P}(5)$ & $\mathrm{C}(11)$ & $1.822(14)$ & $\mathrm{P}(5)$ & $\mathrm{Ta}(2)$ & $\mathrm{P}(5)^{\prime}$ & $156.1(1)$ \\
$\mathrm{P}(5)$ & $\mathrm{C}(12)$ & $1.805(16)$ & $\mathrm{Ta}(1)$ & $\mathrm{P}(4)$ & $\mathrm{C}(7)$ & $116.1(5)$ \\
& & & $\mathrm{Ta}(1)$ & $\mathrm{P}(4)$ & $\mathrm{C}(8)$ & $112.3(5)$ \\
& & & $\mathrm{Ta}(1)$ & $\mathrm{P}(4)$ & $\mathrm{C}(9)$ & $117.8(5)$ \\
& & & $\mathrm{C}(7)$ & $\mathrm{P}(4)$ & $\mathrm{C}(8)$ & $103.6(7)$ \\
& & & $\mathrm{C}(7)$ & $\mathrm{P}(4)$ & $\mathrm{C}(9)$ & $102.3(7)$ \\
& & & $\mathrm{C}(8)$ & $\mathrm{P}(4)$ & $\mathrm{C}(9)$ & $102.9(7)$ \\
& & & $\mathrm{Ta}(2)$ & $\mathrm{P}(5)$ & $\mathrm{C}(10)$ & $115.3(5)$ \\
& & & $\mathrm{Ta}(2)$ & $\mathrm{P}(5)$ & $\mathrm{C}(11)$ & $113.1(5)$ \\
& & & $\mathrm{Ta}(2)$ & $\mathrm{P}(5)$ & $\mathrm{C}(12)$ & $115.9(5)$ \\
& & & $\mathrm{C}(10)$ & $\mathrm{P}(5)$ & $\mathrm{C}(11)$ & $102.2(8)$ \\
& & & $\mathrm{C}(10)$ & $\mathrm{P}(5)$ & $\mathrm{C}(12)$ & $104.0(7)$ \\
& & & $\mathrm{C}(11)$ & $\mathrm{P}(5)$ & $\mathrm{C}(12)$ & $104.8(9)$ \\
\hline
\end{tabular}

(2) Ether solutions of 3 also react readily with hydrogen chloride at $-20^{\circ} \mathrm{C}$ [eqn (3)]:

$$
\begin{aligned}
& \mathrm{Ta}_{2} \mathrm{Cl}_{4}\left(\mathrm{PMe}_{3}\right)_{4} \mathrm{H}_{2}+\mathrm{HCl} \\
& 3 \\
& \underset{1 \mathrm{~h}, \overrightarrow{-20^{\circ} \mathrm{C}}}{\mathrm{OEt}_{2}} \mathrm{Ta}_{2} \mathrm{Cl}_{5}\left(\mathrm{PMe}_{3}\right)_{4} \mathrm{H}_{3} \text {. }
\end{aligned}
$$

A yellow-green solid (4) was isolated by concentration of the suspension and cooling to $-40^{\circ} \mathrm{C}(70 \%$ yield). Elemental analyses and a molecular-weight measurement suggested that 4 was $\mathrm{Ta}_{2} \mathrm{Cl}_{5}(\mathrm{P}$ $\left.\mathrm{Me}_{3}\right)_{4} \mathrm{H}_{3}$. If $\mathrm{HCl}$ adds to 3 in the same fashion as $\mathrm{Cl}_{2}$, we expect a dimer with $C_{2}$-symmetry. The proton and ${ }^{31} \mathrm{P}-\left\{{ }^{1} \mathrm{H}\right\}$ NMR spectra are in accord with this expectation. In the former [Fig. 3(b)], we observe two complex hydride multiplets, one at $\delta$ 9.68 (area 1) and the other at $\delta 7.69$ (area 2), and two phosphine doublets (each of area 18) at $\delta 1.60$ and 1.29. The chemically equivalent $\mathrm{PMe}_{3}$ ligands in the $C_{2}$ structure are magnetically nonequivalent (an $\mathrm{AA}^{\prime} \mathrm{XX}^{\prime}$ spin system), and this is consistent with what we observe in the ${ }^{31} \mathrm{P}-\left\{{ }^{1} \mathrm{H}\right\}$ NMR spectrum (see Experimental).

(3) Ether solutions of 3 react slowly with hydrogen ( $40 \mathrm{psi})$ at $25^{\circ} \mathrm{C}$ [eqn (4)]:

$$
\begin{aligned}
& \mathrm{Ta}_{2} \mathrm{Cl}_{4}\left(\mathrm{PMe}_{3}\right)_{4} \mathrm{H}_{2}+\mathrm{H}_{2} \\
& 3 \\
& \underset{12 \overrightarrow{\mathrm{h}, 25^{\circ} \mathrm{C}}}{\mathrm{OEt}_{2}} \mathrm{Ta}_{2} \mathrm{Cl}_{4}\left(\mathrm{PMe}_{3}\right)_{4} \mathrm{H}_{4} \text {. }
\end{aligned}
$$

to $-40^{\circ} \mathrm{C}(85 \%$ yield). Elemental analyses and a molecular-weight measurement indicated that 5 was $\mathrm{Ta}_{2} \mathrm{Cl}_{4}\left(\mathrm{PMc}_{3}\right)_{4} \mathrm{H}_{4} \cdot{ }^{*}$ Addition of $\mathrm{H}_{2}$ across the metal-metal bond of 3 should provide a dimer with $D_{2 d}$-symmetry. The room-temperature ${ }^{1} \mathrm{H}$ NMR spectrum of 5 [Fig. 3(c)] supports this prediction. A single hydride multiplet is observed at $\delta 8.79$ (area 4) together with one phosphine methyl resonance at $\delta 1.47$ (area 36). Because the hydride resonance is not a simple first-order pattern, we propose that the hydride ligands in $\mathbf{5}$ are static, i.e. they do not rotate about the $\mathrm{Ta}-\mathrm{Ta}$ axis. There was no change in the appearance of the hydride resonance up to $+100^{\circ} \mathrm{C}$ in toluene- $d_{8}$. Higher temperatures led to decomposition. The ${ }^{31} \mathrm{P}-\left\{{ }^{1} \mathbf{H}\right\}$ NMR spectrum of $5\left(C_{6} D_{6}, 25^{\circ} \mathrm{C}\right)$ shows a singlet at $\delta-1.8$. Selective ${ }^{1} \mathrm{H}$-decoupling of the phosphine methyl resonance broadened this peak, but we were unable to resolve any fine structure. Because the spin system is complex ( $\left.\mathrm{AA}^{\prime} \mathrm{A}^{\prime \prime} \mathrm{A}^{\prime \prime} \mathrm{X} \mathrm{X}^{\prime} \mathrm{X}^{\prime \prime} \mathrm{X}^{\prime \prime}\right)$, this result is not particularly surprising. Below, we provide definitive proof for the proposed structure of 5, but first we would like to describe an alternate, and more convenient, synthesis of 5 .

\section{Synthesis of 5 from $\mathrm{TaCl}_{2} \mathrm{H}_{2}\left(\mathrm{PMe}_{3}\right)_{4}$}

The deep red tantalum(IV) hydride complex, $\mathrm{TaCl}_{2} \mathrm{H}_{2}\left(\mathrm{PMe}_{3}\right)_{4}$ (6) can be synthesized, in high yield $\left(\geqslant 75 \%\right.$ ) via reduction of $\mathrm{TaCl}_{5}$ with sodium

*This dimer has been prepared independently by Fellmann ${ }^{12(b)}$ and Schrock from monomeric $\mathrm{Ta}\left(\mathrm{CHCMe}_{3}\right)(\mathrm{H}) \mathrm{Cl}_{2}\left(\mathrm{PMe}_{3}\right)_{3}$ and molecular hydrogen.
A yellow-green solid (5) was isolated from the reaction suspension by concentration and cooling 
$\left[\mathrm{TaCl}_{2}\left(\mathrm{PMe}_{3}\right)_{2}\right]_{2}(\mu-\mathrm{H})_{2}(\mu-\mathrm{Cl})_{2}$
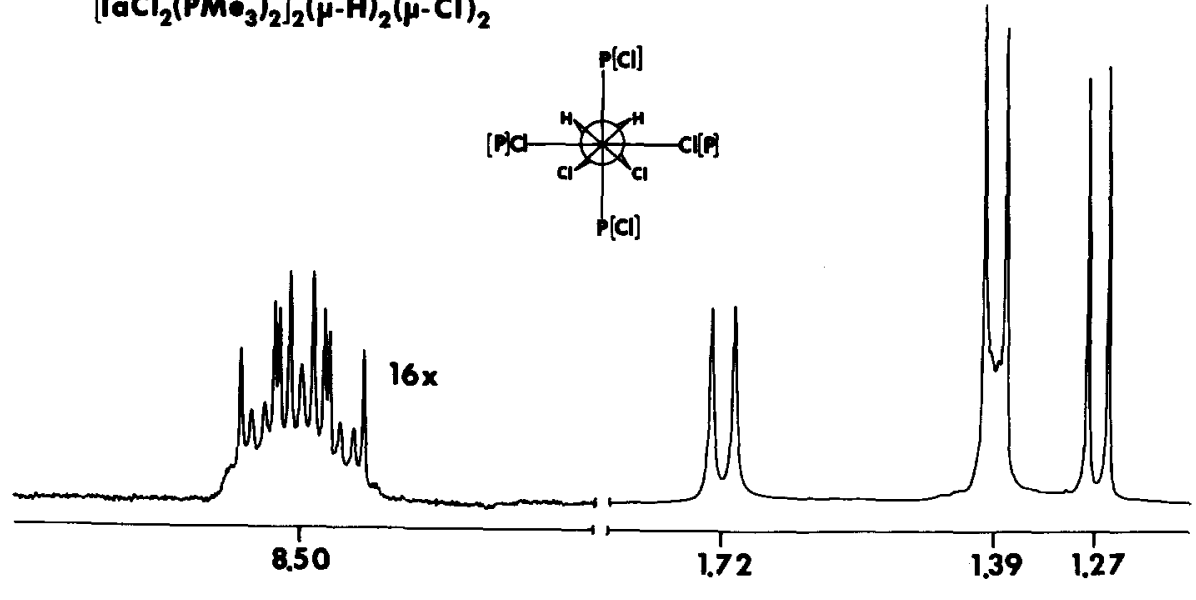

(a)

$\left[\mathrm{TaCl}_{2}\left(\mathrm{PMo}_{3}\right)_{2}\right]_{2}(\mu-\mathrm{H})_{3}(\mu-\mathrm{Cl})$

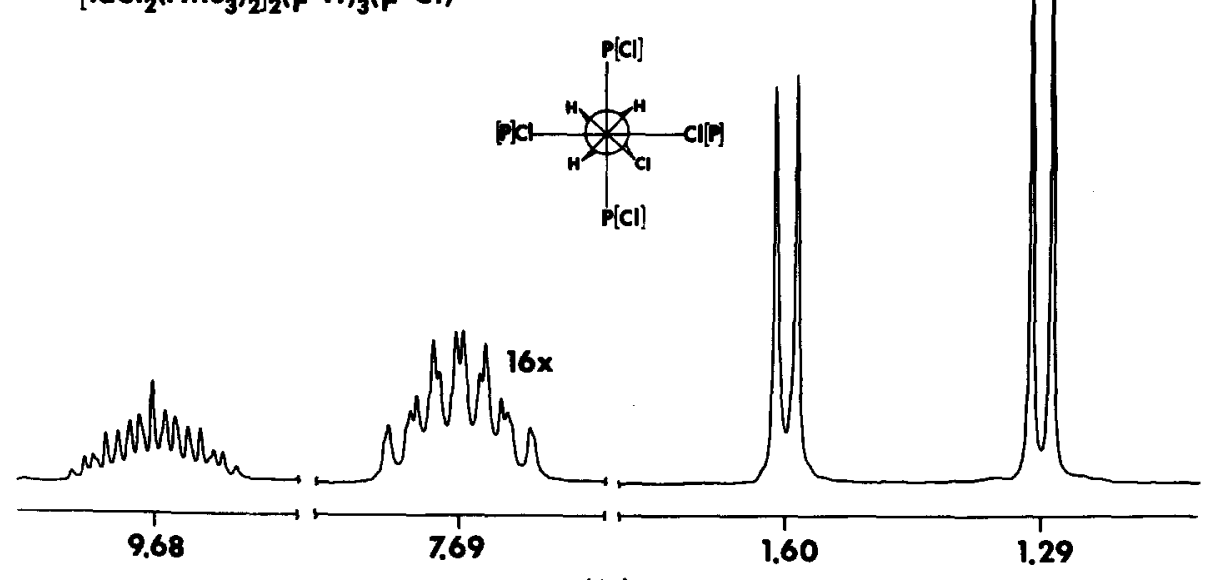

(b)

$\left[\mathrm{TaCl}_{2}\left(\mathrm{PM}_{3}\right)_{2}\right]_{2}(\mu-\mathrm{H})_{4}$
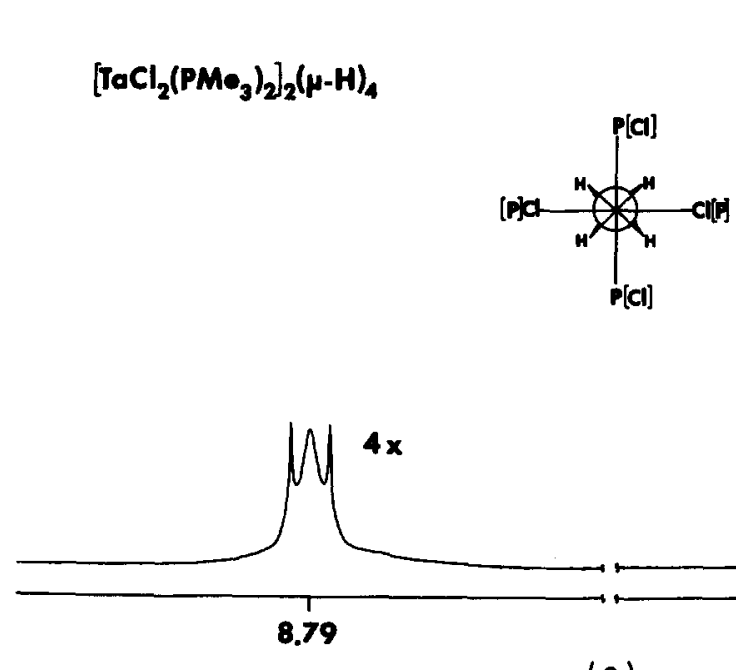

(c)

Fig. 3. 360-MHz ${ }^{1} \mathrm{H}$ NMR spectra of: (a) $\mathrm{Ta}_{2} \mathrm{Cl}_{6}\left(\mathrm{PMe}_{3}\right)_{4} \mathrm{H}_{2}$, (b) $\mathrm{Ta}_{2} \mathrm{Cl}_{5}\left(\mathrm{PMe}_{3}\right)_{4} \mathrm{H}_{3}$, and (c) $\mathrm{Ta}_{2} \mathrm{Cl}_{4}\left(\mathrm{PMe}_{3}\right)_{4} \mathrm{H}_{4}$. 
amalgam ( 3 equivalents) in ether and subsequent treatment with molecular hydrogen. ${ }^{13}$ The reducreduction step generates the tantalum(II) monomer, trans- $\mathrm{TaCl}_{2}\left(\mathrm{PMe}_{3}\right)_{4}$, which then oxidatively adds hydrogen to give the paramagnetic dihydride. The latter, as well as its 1,2-bis(dimethylphosphino)ethane analog, $\mathrm{TaCl}_{2} \mathrm{H}_{2}$ (dmpe) ${ }_{2}$, have been fully characterized by solution and solid-state ESR, magnetic-susceptibility measurements, and X-ray crystallography. ${ }^{13,14}$ As we commented earlier, ${ }^{13}$ the isolation of 6 was quite unexpected. We thought that it would decompose to $\mathbf{5}$ and free phosphine as fast as it was formed. This prejudice was based on a popular misconception that paramagnetic early transition metal hydrides were simply too unstable to permit isolation. ${ }^{15} 6$ does decompose to 5 in solution at $25^{\circ} \mathrm{C}$, but the reaction is very slow because the liberated trimethylphosphine inhibits further decomposition of the monomer [eqn (5)]:

$$
\begin{aligned}
2 \mathrm{TaCl}_{2} \mathrm{H}_{2}\left(\mathrm{PMe}_{3}\right)_{4} \\
6 \\
\underset{2}{\underset{2 \mathrm{~s}^{\circ} \mathrm{C}}{\mathrm{C}_{6} \mathrm{H}_{6}}} \mathrm{Ta}_{2} \mathrm{Cl}_{4}\left(\mathrm{PMe}_{3}\right)_{4} \mathrm{H}_{4}+4 \mathrm{PMe}_{3} .
\end{aligned}
$$

In an open system at higher temperatures, however, 6 decomposes readily to 5 . Refluxing methylcyclohexane (b.p. $101^{\circ} \mathrm{C}$ ) is quite suitable for this purpose. This route is a considerable improvement over the original four-step $\left(\mathrm{TaCl}_{5} \rightarrow \mathbf{1} \rightarrow 3 \rightarrow 5\right.$ ) procedure and provides 5 in $\mathrm{ca} 65 \%$ yield based on tantalum pentachloride.

\section{Solid state structure of $\mathbf{5}$}

In the crystalline state, the compound is composed of discrete molecules of $\mathbf{5}$. Final atomic coordinates and isotropic thermal parameters are listed in Table 3. Interatomic distances and angles are provided in Table 4 . The molecular geometry and atom-numbering scheme are shown in Fig. 4. The pseudo-square planes of chloro and $\mathrm{PMe}_{3}$ ligands are in the eclipsed conformation, the phosphine ligands are staggered among themselves, and the bridging $\mathrm{H}_{4}$ group is staggered by $45^{\circ}$ with respect to the end groups. The molecular symmetry, $D_{2 d}$, is a requirement of the tetragonal space group $P 4 / n b m(Z=2)$.

The Ta-Ta-Cl and Ta-Ta-P bond angles in 5 are $121.6(1)$ and $110.3(1)^{\circ}$, respectively. Both are more obtuse than their counterparts in 3 and the increases of $5-8^{\circ}$ are almost certainly a reflection of the decrease in the metal-metal separation going from $3[\mathrm{Ta}=\mathrm{Ta}, 2.545(1) \AA]$ to 5 [Ta-Ta,
Table 3. Fractional coordinates and isotropic thermal parameters for $\mathrm{Ta}_{2} \mathrm{Cl}_{4}\left(\mathrm{PMe}_{3}\right)_{4} \mathrm{H}_{4}{ }^{a}$

\begin{tabular}{lcccl}
\hline Atom & $x$ & $y$ & $z$ & $B_{\text {iso }}$ \\
\hline $\mathrm{Ta}(1)$ & $7500^{*}$ & $2500^{*}$ & $3770(1)$ & 18 \\
$\mathrm{Cl}(2)$ & $8678(3)$ & $1322^{*}$ & $2505(6)$ & 29 \\
$\mathrm{P}(3)$ & $6127(3)$ & $3873^{*}$ & $-2886(6)$ & 24 \\
$\mathrm{C}(4)$ & $6012(19)$ & $3988^{*}$ & $-1117(26)$ & 42 \\
$\mathrm{C}(5)$ & $6380(18)$ & $-215(14)$ & $3470(22)$ & 47 \\
$\mathrm{H}(1)$ & $669^{*}$ & $82^{*}$ & $73^{*}$ & 53 \\
$\mathrm{H}(2)$ & $550^{*}$ & $450^{*}$ & $-86^{*}$ & 52 \\
$\mathrm{H}(3)$ & $581^{*}$ & $-68^{*}$ & $321^{*}$ & 55 \\
$\mathrm{H}(4)$ & $702^{*}$ & $-48^{*}$ & $308^{*}$ & 55 \\
$\mathrm{H}(5)$ & $645^{*}$ & $-23^{*}$ & $439^{*}$ & 55 \\
$\mathrm{H}(6)$ & $750(14)$ & $354(15)$ & $500(13)$ & $21(51)$ \\
\hline
\end{tabular}

asee footnote to Table 1 .

2.511(2) $\AA$ ]. In the bridge region, the $\mathrm{Ta}-\mathrm{H}_{\mathrm{b}}$ distance is $1.81(21) \AA$ and the $\mathrm{Ta}-\mathrm{H}_{\mathrm{b}}-\mathrm{Ta}$ angle is $88(4)^{\circ}$. The only other structurally characterized $(\mu-\mathrm{H})_{4}$ dimer is $\mathrm{Re}_{2} \mathrm{H}_{8}\left(\mathrm{PEt}_{2} \mathrm{Ph}\right)_{4}{ }^{16}$ Here the metal-metal separiation is $2.538(4) \AA$, the $\mathrm{Re}-\mathrm{H}_{\mathrm{b}}$ distance is $1.878(7) \AA$, and the $\operatorname{Re}-\mathrm{H}_{\mathrm{b}}-\mathrm{Re}$ angle is $85.0(3)^{\circ}$ (neutron diffraction data).

\section{Electronic structure calculations}

Why is it that the briding hydrides in $\mathbf{5}$ do not rotate about the metal-metal bond axis? Why do the bridging hydrides in 3 rotate rapidly about the metal-metal bond axis? In order to answer these questions, we calculated the ground-state electronic structures of the model compounds $\mathrm{Ta}_{2} \mathrm{Cl}_{4}\left(\mathrm{PH}_{3}\right)_{4} \mathrm{H}_{4}$ and $\mathrm{Ta}_{2} \mathrm{Cl}_{4}\left(\mathrm{PH}_{3}\right)_{4} \mathrm{H}_{2}$ using the multiple-scattering $\mathrm{X} \alpha$ method. ${ }^{17 *}$ For each of these models, the calculation of $\mathrm{X} \alpha$ eigenvalues was first carried out nonrelativistically. Relativistic corrections ${ }^{18}$ were then added, and the calculations were reconverged. Additional information on the calculations is provided in Experimental.

\section{$\mathrm{Ta}_{2} \mathrm{Cl}_{4}\left(\mathrm{PH}_{3}\right)_{4} \mathrm{H}_{4}$}

The results of the calculations are displayed in Fig. 5, which shows both the nonrelativistic levels and those obtained after approximate relativistic corrections were applied. The energies of the relativistic levels and the atomic contributions to them are presented in Table 5 . The levels fall naturally into a number of small groups; these will be discussed in turn.

*The programs we used were written by M. Cook, Harvard University, and B. E. Bursten and G. G. Stanley, Texas A\&M University. We are grateful to Professor Bruce Bursten (Ohio State University) for a copy of the programs. 
A. J. SCIOLY et al.

Table 4. Selected bond distances $(\AA)$ and angles $\left(^{\circ}\right)$ for $\mathrm{Ta}_{2} \mathrm{Cl}_{4}(\mathrm{P}$ $\left.\mathrm{Me}_{3}\right)_{4} \mathrm{H}_{4}$

\begin{tabular}{lllllll}
\hline \multicolumn{1}{r}{$\mathrm{A}$} & \multicolumn{1}{c}{$\mathrm{B}$} & \multicolumn{1}{c}{ Distance } & \multicolumn{1}{c}{$\mathrm{A}$} & $\mathrm{B}$ & $\mathbf{C}$ & Angle \\
\hline $\mathrm{Ta}(1)$ & $\mathrm{Ta}(1)^{\prime}$ & $2.511(2)$ & $\mathrm{Ta}(1)^{\prime}$ & $\mathrm{Ta}(1)$ & $\mathrm{Cl}(2)$ & $121.6(1)$ \\
$\mathrm{Ta}(1)$ & $\mathrm{Cl}(2)$ & $2.461(5)$ & $\mathrm{Ta}(1)^{\prime}$ & $\mathrm{Ta}(1)$ & $\mathrm{P}(3)$ & $110.3(1)$ \\
$\mathrm{Ta}(1)$ & $\mathrm{P}(3)$ & $2.604(5)$ & $\mathrm{Cl}(2)^{\prime}$ & $\mathrm{Ta}(1)$ & $\mathrm{Cl}(2)$ & $116.7(3)$ \\
$\mathrm{P}(3)$ & $\mathrm{C}(4)$ & $1.817(22)$ & $\mathrm{Cl}(2)$ & $\mathrm{Ta}(1)$ & $\mathrm{P}(3)$ & $79.5(1)$ \\
$\mathrm{P}(3)$ & $\mathrm{C}(5)$ & $1.818(16)$ & $\mathrm{P}(3)^{\prime}$ & $\mathrm{Ta}(1)$ & $\mathrm{P}(3)$ & $139.5(2)$ \\
$\mathrm{Ta}(1)$ & $\mathrm{H}(6)$ & $1.81(21)$ & $\mathrm{Ta}(1)$ & $\mathrm{P}(3)$ & $\mathrm{C}(4)$ & $116.7(9)$ \\
& & & $\mathrm{Ta}(1)$ & $\mathrm{P}(3)$ & $\mathrm{C}(5)$ & $112.7(5)$ \\
& & & $\mathrm{C}(4)$ & $\mathrm{P}(3)$ & $\mathrm{C}(5)$ & $105.4(8)$ \\
& & & $\mathrm{C}(5)$ & $\mathrm{P}(3)$ & $\mathrm{C}(5)^{\prime}$ & $102.6(12)$ \\
& & & $\mathrm{Ta}(1)^{\prime}$ & $\mathrm{Ta}(1)$ & $\mathrm{H}(6)$ & $46 .(3)$ \\
& & & $\mathrm{Cl}(2)$ & $\mathrm{Ta}(1)$ & $\mathrm{H}(6)$ & $143 .(6)$ \\
& & & $\mathrm{P}(3)$ & $\mathrm{Ta}(1)$ & $\mathrm{H}(6)$ & $136 .(6)$ \\
& & & $\mathrm{Ta}(1)^{\prime}$ & $\mathrm{H}(6)$ & $\mathrm{Ta}(1)$ & $88 .(4)$ \\
\hline
\end{tabular}

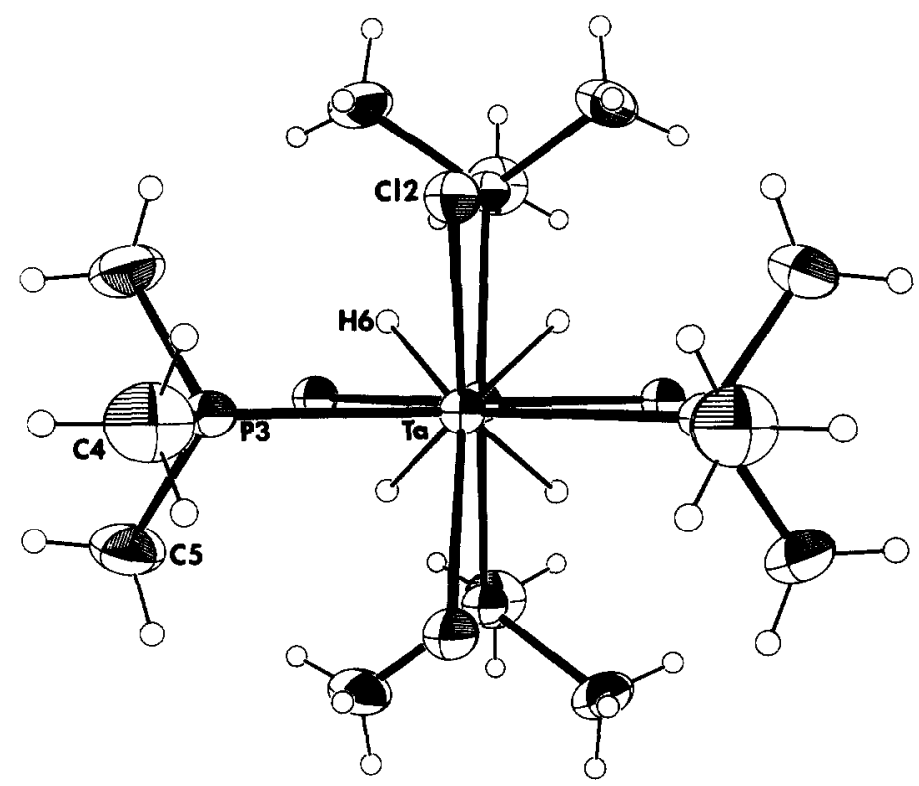

Fig. 4. ORTEP drawing of $\mathrm{Ta}_{2} \mathrm{Cl}_{4}\left(\mathrm{PMe}_{3}\right)_{4} \mathrm{H}_{4}$. Each nonhydrogen atom is represented by a thermal vibration ellipsoid enclosing $50 \%$ of its electron density. $D_{2 d}$-symmetry is a space group requirement (see text).

First, we examine the highest occupied molecular orbital (HOMO) and the low-lying virtual orbitals. As seen from the breakdown in Table 5, both the HOMO $\left(8 a_{1}\right)$ and the lowest unoccupied molecular orbital (LUMO) $\left(3 a_{2}\right)$ are metal localized with modest contributions from the chloro and phosphorus ligands. A cross-section of the HOMO is shown in Fig. 6. The $\mathrm{Ta}-\mathrm{Ta}$ interaction is a bonding one, arising from overlap of the $5 d_{z 3}$ orbitals. There is also evidence of $\mathrm{Ta}-\mathrm{P}$ bonding and $\mathrm{Ta}-\mathrm{Cl}$ antibonding here. The bridging hydrogens make a negligible contribution to this level, which is clearly a Ta-Ta $\sigma$-bond. The LUMO (not pictured here) is essentially the $\delta^{*}$-orbital, i.e. the out-of-phase combination of the $5 d_{x y}$ orbitals on the tantalum centers. The HOMO-LUMO gap is $1.26 \mathrm{eV}$. Other virtual orbitals of note are the $7 b_{2}$ and the $10 e$. These are the Ta-Ta $\sigma^{*}$-and $\pi^{*}$-levels, respectively.

Lying below the HOMO are four groups of levels (see Fig. 5): (1) the $\mathrm{Ta}-\mathrm{P} \sigma$-bonding orbitals (9e, $7 a_{1}, 6 b_{2} ;-6.5$ to $\left.-7.8 \mathrm{eV}\right)$; (2) the chlorine lone pair orbitals $\left(3 b_{1}, 8 e, 2 a_{2}, 7 e, 5 b_{2}, 6 a_{1} ;-8.1\right.$ to $-8.7 \mathrm{eV}$ ); (3) the $\mathrm{Ta}-\mathrm{Cl} \sigma$-bonding orbitals $(6 e$, $5 a_{1}, 4 b_{2} ;-9.0$ to $\left.-9.7 \mathrm{eV}\right) ;(4)$ the $\mathrm{P}-\mathrm{H} \sigma$-bonding orbitals $\left(5 e, 1 a_{2}, 4 e, 1 b_{1}, 3 b_{2}, 4 a_{1} ;-11.8\right.$ to $-12.0 \mathrm{eV}$ ). Both the ordering and the energies of these levels are in accordance with an earlier MS$\mathrm{X} \alpha$ calculation on $\mathrm{W}_{2} \mathrm{Cl}_{4}\left(\mathrm{PH}_{3}\right)_{4} \cdot{ }^{19}$

The four remaining occupied levels in Fig. 5 and Table 5 are those which describe the $\sigma-, \pi$ and $\delta$ - 


\section{$\left[\mathrm{TaCl}_{2}\left(\mathrm{PH}_{3}\right)_{2}\right]_{2}(\mu-\mathrm{H})_{4}$}

Non-Rolativistic

Relotivistic

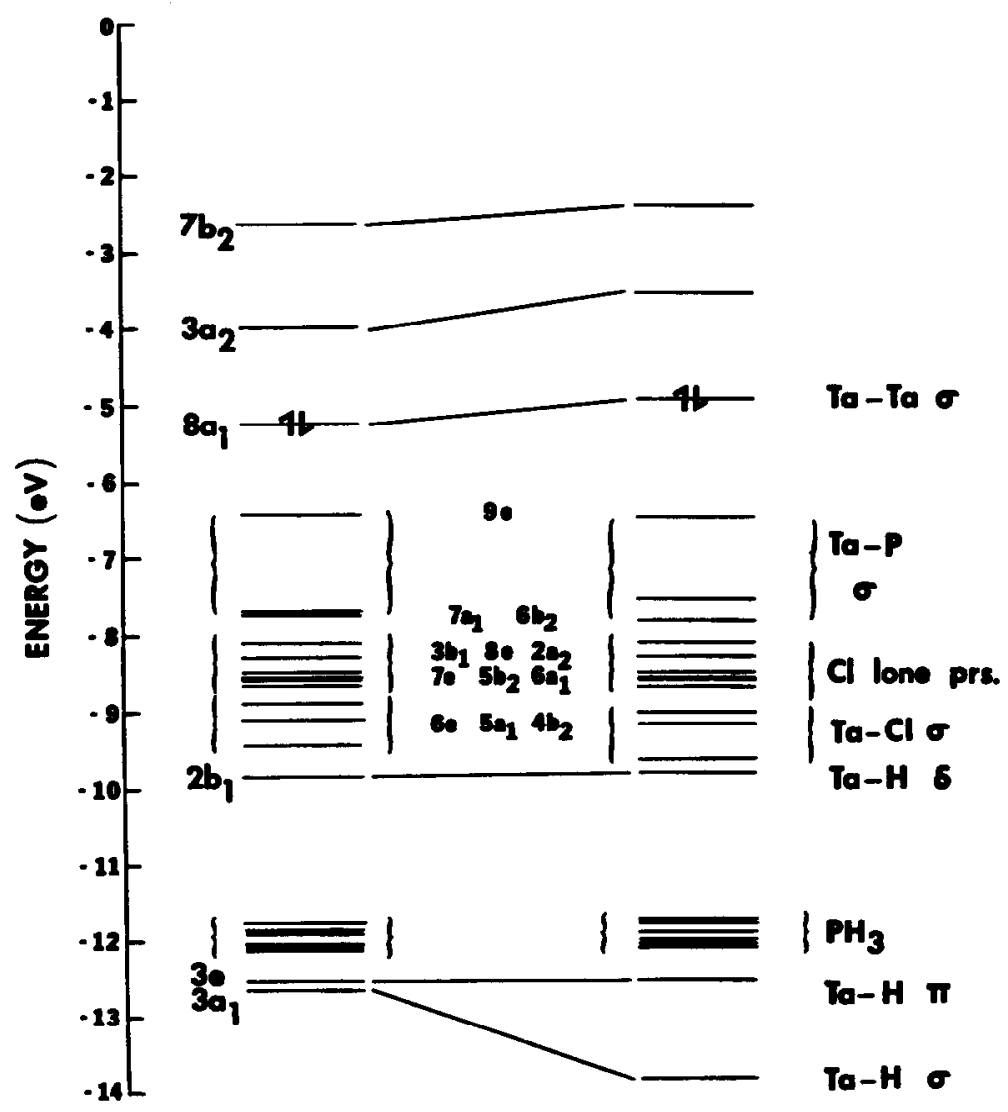

Fig. 5. Summary of the nonrelativistic and relativistic eigenvalues for the model complex $\mathrm{Ta}_{2} \mathrm{Cl}_{4}\left(\mathrm{PH}_{3}\right)_{4} \mathrm{H}_{4}$.

type interactions between the tantalum atoms and the four bridging hydride ligands. The lowest-lying of these is the $\sigma\left(3 a_{1},-13.9 \mathrm{eV}\right)$ and a cross-section of this level is shown in Fig. 7. The interaction here is between the in-phase combination of all four hydrogen $1 s$ orbitals, and a pair of tantalum hybrid orbitals $\left(62 \% 6 s, 23 \% 6 p_{z}\right.$ and $\left.14 \% 5 d_{z^{2}}\right)$. The substantial tantalum $6 s$ character in this level is responsible for its marked stabilization. Note also that this is the only level which drops dramatically in energy when relativistic corrections are introduced into the calculations (see Fig. 5). This extra stabilization of the $3 a_{1}$ level is a direct consequence of its high tantalum $s+p$ character. ${ }^{20}$

At somewhat higher energy are the degenerate $\pi$-type levels $(3 e,-12.5 \mathrm{eV})$, one of which is shown in Fig. 8. Here we have another strong, stabilizing interaction. This one is primarily between the tantalum $5 d_{ \pm 1}$ orbitals (note the lobular structure about each $\mathrm{Ta}$ ) and an antisymmetric combination of hydrogen $1 \mathrm{~s}$ orbitals. Finally, at $-9.8 \mathrm{eV}$, we find the $2 b_{1}$ or $\delta$-type level. In-phase overlap of the tantalum $5 d_{x y}$ orbitals with the bridging ligand orbitals is the genesis of this level. A cross-section of the $2 b_{1}$ level shows the $\delta$-symmetry quite clearly (Fig. 9).

Now that we have a good picture of the $\mathrm{M}-\mathrm{M}$ and $\mathrm{M}-\mathrm{H}-\mathrm{M}$ interactions in $\mathrm{Ta}_{2} \mathrm{Cl}_{4}\left(\mathrm{PH}_{3}\right)_{4} \mathrm{H}_{4}$, we are in a position to address the question of $(\mu$ $\mathrm{H}_{4}$ rotation in 5. The $\sigma$ - and $\pi$-interactions are cylindrically symmetric with respect to the $\mathrm{Ta}-$ Ta axis and do not engender a conformational preference for the bridging hydride ligands. The same cannot be said for the $\mathrm{TaH}_{4} \mathrm{Ta} \delta$-interaction. This bridge bonding component will stabilize the staggered hydride conformation relative to the eclipsed hydride conformation.* Unfortunately, ground-state calculations of the type reported here

* Similar conclusions have been reached in the case of $\mathrm{Re}_{2} \mathrm{H}_{8}\left(\mathrm{PH}_{3}\right)_{4}$, a model for $\mathrm{Re}_{2} \mathrm{H}_{8}\left(\mathrm{PEt}_{2} \mathrm{Ph}\right)_{4} \cdot{ }^{16,21}$ 
A. J. SCIOLY et al.

Table 5. MA-X $\alpha$ eigenvalues (including relativistic corrections) for $\mathrm{Ta}_{2} \mathrm{Cl}_{4}\left(\mathrm{PH}_{3}\right)_{4} \mathrm{H}_{4}{ }^{a}$

\begin{tabular}{|c|c|c|c|c|c|c|c|c|c|c|c|c|c|}
\hline \multirow{3}{*}{$\frac{\text { Level }}{4 b}$} & \multirow{3}{*}{$\begin{array}{c}\begin{array}{c}\text { Energy } \\
(\mathrm{EV})\end{array} \\
-0.896\end{array}$} & \multicolumn{8}{|c|}{$\%$ Contribution } & & & & \\
\hline & & $\mathrm{Ta}$ & $\mathrm{Cl}$ & $\mathbf{P}$ & H1 & $\mathrm{H} 2$ & $\mathrm{H3}$ & Int & Out & \multicolumn{4}{|c|}{ Ta angular contributions } \\
\hline & & 15 & 3 & 10 & 1 & 0 & 4 & 60 & 7 & $89 \% \mathrm{D}$ & $11 \% \mathrm{~F}$ & & \\
\hline $11 e^{2}$ & -1.004 & 5 & 3 & 5 & 0 & 1 & 0 & 78 & 9 & & & & \\
\hline $10 a_{1}$ & -1.249 & 37 & 9 & 15 & 0 & 0 & 1 & 33 & 5 & $1 \% \mathrm{P}$ & $98 \% \mathrm{D}$ & $1 \% \mathrm{~F}$ & \\
\hline $9 a_{1}$ & -1.385 & 16 & 7 & 6 & 0 & 1 & 0 & 62 & 7 & $4 \% \mathrm{~S}$ & $95 \% \mathrm{D}$ & $1 \% \mathrm{~F}$ & \\
\hline $8 b_{2}$ & -1.614 & 44 & 9 & 16 & $\theta$ & 2 & 0 & 26 & 3 & $4 \% \mathrm{P}$ & $94 \% \mathrm{D}$ & $2 \% \mathrm{~F}$ & \\
\hline $10 e^{2}$ & -1.637 & 69 & 10 & 7 & 1 & 0 & 0 & 12 & 1 & $99 \% \mathrm{D}$ & $1 \% \mathrm{~F}$ & & \\
\hline $7 b_{2}$ & -2.505 & 65 & 17 & 1 & 0 & 0 & 0 & 16 & 0 & $3 \% \mathrm{~S}$ & $3 \% \mathrm{P}$ & $93 \% \mathrm{D}$ & $1 \% \mathrm{~F}$ \\
\hline $3 a_{2}$ & -3.671 & 74 & 8 & 2 & 1 & 0 & 0 & 14 & 0 & $100 \% \mathrm{D}$ & & & \\
\hline $8 a_{1}$ & -4.932 & 59 & 14 & 7 & 0 & 1 & 4 & 15 & 0 & $1 \% \mathrm{P}$ & $96 \% \mathrm{D}$ & $3 \% \mathrm{~F}$ & \\
\hline $9 e^{2}$ & -6.514 & 11 & 14 & 49 & 5 & 2 & 0 & 18 & 1 & $38 \% \mathrm{P}$ & $58 \% \mathrm{D}$ & $4 \% \mathrm{~F}$ & \\
\hline $7 a_{1}$ & -7.671 & 36 & 0 & 42 & 5 & 1 & 1 & 13 & 1 & $2 \% \mathrm{~S}$ & $6 \% \mathrm{P}$ & $91 \% \mathrm{D}$ & $1 \% \mathrm{~F}$ \\
\hline $6 b_{2}$ & -7.822 & 26 & 11 & 39 & 6 & 1 & 0 & 16 & 1 & $14 \% \mathrm{~S}$ & $85 \% \mathrm{D}$ & $1 \% \mathrm{~F}$ & \\
\hline $3 b_{1}$ & -8.166 & 5 & 73 & 0 & 0 & 0 & 10 & 12 & 0 & & & & \\
\hline $8 e$ & -8.376 & 1 & 84 & 0 & 0 & 0 & 1 & 14 & 0 & & & & \\
\hline $2 a_{2}$ & -8.559 & 4 & 79 & 2 & 2 & 0 & 0 & 13 & 0 & & & & \\
\hline $7 e$ & -8.684 & 3 & 71 & 7 & 1 & 1 & 0 & 16 & 0 & & & & \\
\hline $5 b_{2}$ & 8.692 & 5 & 72 & 5 & 0 & 1 & 0 & 16 & 0 & & & & \\
\hline $6 a_{1}$ & -8.728 & 5 & 75 & 1 & 0 & 1 & 1 & 16 & 0 & & & & \\
\hline $6 e$ & -9.059 & 12 & 77 & 1 & 1 & 0 & 2 & 7 & 1 & $43 \% P$ & $54 \% \mathrm{D}$ & $4 \% \mathrm{~F}$ & \\
\hline $5 a_{1}$ & -9.239 & 19 & 73 & 0 & 0 & 0 & 3 & 5 & 1 & $2 \% S$ & $22 \% \mathrm{P}$ & $72 \% \mathrm{D}$ & $3 \% \mathrm{~F}$ \\
\hline $4 b_{2}$ & -9.711 & 16 & 73 & 2 & 0 & 0 & 0 & 8 & 0 & $48 \% \mathrm{~S}$ & $9 \% \mathrm{P}$ & $40 \% \mathrm{D}$ & $3 \% \mathrm{~F}$ \\
\hline $2 b_{1}$ & -9.814 & 33 & 10 & 4 & 6 & 0 & 39 & 7 & 0 & $91 \% \mathrm{D}$ & $9 \% \mathrm{~F}$ & & \\
\hline Se & -11.817 & 5 & 1 & 42 & 43 & 5 & 4 & 0 & 0 & & & & \\
\hline $1 a_{2}$ & -11.892 & 0 & 1 & 46 & 52 & 0 & 0 & 0 & 0 & & & & \\
\hline $4 e^{2}$ & -11.916 & 4 & 0 & 42 & 24 & 25 & 4 & 0 & 1 & & & & \\
\hline $1 b_{1}$ & -11.999 & 2 & 2 & 45 & 50 & 0 & 2 & 0 & 0 & & & & \\
\hline $3 b_{2}$ & -12.029 & 0 & 0 & 46 & 18 & 35 & 0 & 0 & 1 & & & & \\
\hline $4 a_{1}$ & -12.046 & 1 & 1 & 45 & 18 & 34 & 0 & 0 & 0 & & & & \\
\hline $3 e$ & -12.553 & 35 & 2 & 10 & 4 & 6 & 40 & 3 & 0 & $12 \% \mathrm{P}$ & $83 \% \mathrm{D}$ & $5 \% \mathrm{~F}$ & \\
\hline $3 a_{1}$ & -13.908 & 41 & 5 & 3 & 0 & 1 & 46 & 4 & 0 & $62 \% \mathrm{~S}$ & $23 \% \mathrm{P}$ & $14 \% \mathrm{D}$ & \\
\hline
\end{tabular}

${ }^{a}$ Chlorine $3 s$, phosphorus $3 s$, and core levels have been omitted. The HOMO is $8 a_{1}, \mathrm{H} 1$ and $\mathrm{H} 2$ refer to the out-of-plane and in-plane $\mathrm{PH}_{3}$ hydrogens, respectivcly (see text). $\mathrm{H} 3$ refers to the bridge hydrogens.

$8 a_{1}$ LEVEL $\left(\mathrm{TaCl}_{2}\left(\mathrm{PH}_{3}\right)_{2}\right)_{2}(\mu-\mathrm{H})_{4}$

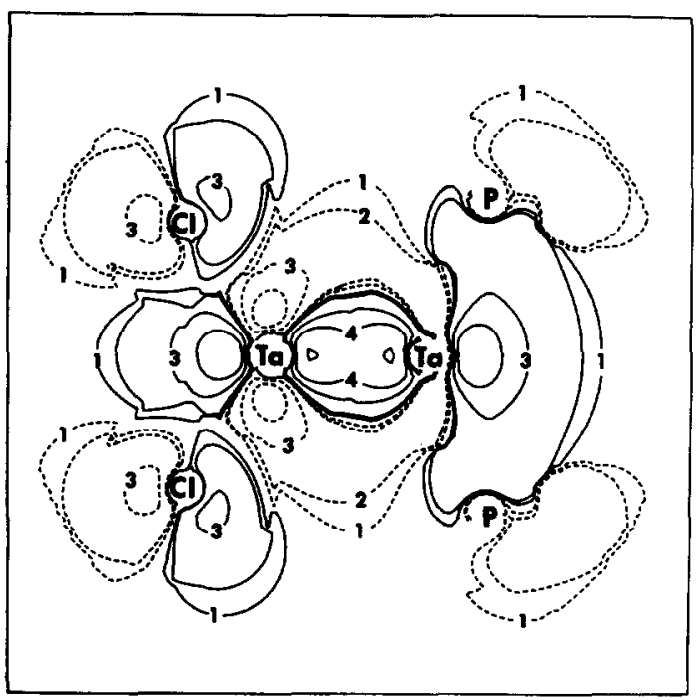

Fig. 6. Cross-section of the $8 a_{1}$ level (HOMO) of $\mathrm{Ta}_{2} \mathrm{Cl}_{4}\left(\mathrm{PH}_{3}\right)_{4} \mathrm{H}_{4}$. For this and all other diagrams, solid lines represent positive wave function values and dashed lines represent negative values. The number 1 represents 0.005 electrons bohr ${ }^{-3}$, and each succeeding number represents a factor of two increase in electron density, except for 7 , which stands for 0.22 electron bohr ${ }^{-3}$. do not provide any information on the energetics of $(\mu-\mathrm{H})_{4}$ rotation about the metal-metal bond. All we can say is that our inability to effect an averaging of spin couplings in 5 from 25 to $100^{\circ} \mathrm{C}$ is consistent with the presence of a substantial $\delta$-interaction which effectively "locks" the hydride ligands into the staggered conformation. Hoffmann and coworkers ${ }^{21}$ have calculated (using extended Hückel methods) a $35 \mathrm{kcal} \mathrm{mol}^{-1}$ barrier to $(\mu-\mathrm{H})_{4}$ rotation in $\mathrm{Re}_{2} \mathrm{H}_{8}\left(\mathrm{PH}_{3}\right)_{4}$, a model for structurally characterized $\mathrm{Re}_{2} \mathrm{H}_{8}\left(\mathrm{PEt}_{2} \mathrm{Ph}\right)_{4}{ }^{16}$ whose $(\mu-\mathrm{H})_{4}$ group is also staggered by $45^{\circ}$ with respect to its eclipsed pyramidal $\mathrm{ReH}_{2}\left(\mathrm{PEt}_{2} \mathrm{Ph}\right)_{2}$ end groups. We do not expect a significant difference between $(\mu-\mathrm{H})_{4}$ rotation barriers in the rhenium(IV) and tantalum(IV) dimers because the orbitals which are depopulated $(\operatorname{Re} \rightarrow \mathrm{Ta})$ are essentially pure $\mathbf{M}-\mathbf{M}$ $\sigma^{*}$ - and $\delta^{*}$-orbitals and are therefore unaffected by $(\mu-\mathrm{H})_{4}$ rotation. Note that a barrier greater than $c a$ $20 \mathrm{kcal} \mathrm{mol}^{-1}$ is all that is required to account for our failure to observe an averaging of spin couplings at $+100^{\circ} \mathrm{C}$.

\section{$\mathrm{Ta}_{2} \mathrm{Cl}_{4}\left(\mathrm{PH}_{3}\right)_{4} \mathrm{H}_{2}$}

The overall electronic structure of this $D_{2}$ model compound is quite similar to that of the quadruply 
$3 a_{1}$ LEVEL * $\left(\mathrm{TaCl}_{2}\left(\mathrm{PH}_{3}\right)_{2}\right)_{2}(\mu-\mathrm{H})_{4}$

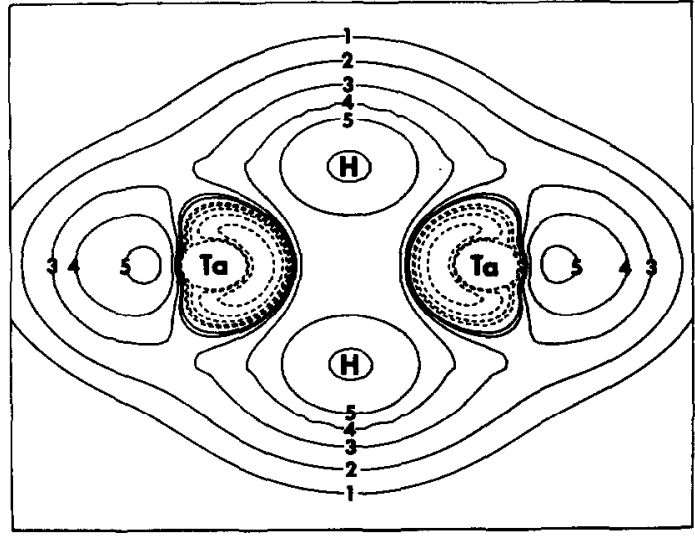

Fig. 7. Cross-section of the $3 a_{1}$, level( $\mathrm{Ta}-\mathrm{H} \sigma$-interaction) of $\mathrm{Ta}_{2} \mathrm{Cl}_{4}\left(\mathrm{PH}_{3}\right)_{4} \mathrm{H}_{4}$.

3e LEVEL * $\left(\mathrm{TaCl}_{2}\left(\mathrm{PH}_{3}\right)_{2}\right)_{2}\left(\mu-\mathrm{H}_{4}\right.$

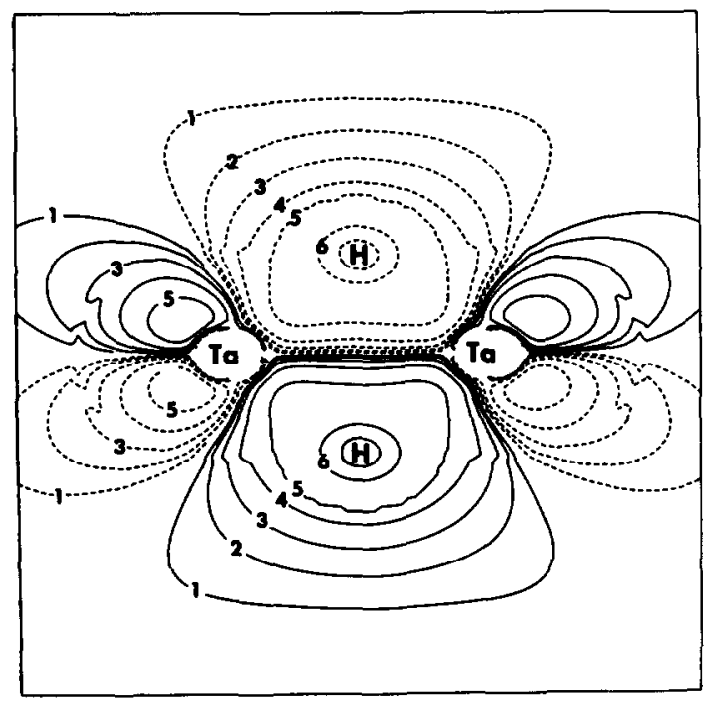

Fig. 8. Cross-section of one component of the $3 e$ level (Ta-H $\pi$-interaction) of $\mathrm{Ta}_{2} \mathrm{Cl}_{4}\left(\mathrm{PH}_{3}\right)_{4} \mathrm{H}_{4}$.

hydrogen-bridged $D_{2 x^{\prime}}$ dimer described ahove and we wihn not discuss it in detaî. Rather, the locus here will be specific changes brought about by removal of two bridging hydrides.

The relativistic energy eigenvalues obtained for $\mathrm{Ta}_{2} \mathrm{Cl}_{4}\left(\mathrm{PH}_{3}\right)_{4} \mathrm{H}_{2}$ are listed in Table 6. Figure $\mathrm{IO}$ is a correlation diagram showing schematically bow the Ta-H-Ta interactions change in going from $\mathrm{Ta}_{2} \mathrm{Cl}_{4}\left(\mathrm{PH}_{3}\right)_{4} \mathrm{H}_{4}$ to $\mathrm{Ta}_{2} \mathrm{Cl}_{4}\left(\mathrm{PH}_{3}\right)_{4} \mathrm{H}_{2}$. The $\sigma$-interaction remains strong. A cross-section of the $5 a$ level of the $(\mu-\mathrm{H})_{2}$ dimer is very similar to the $3 a_{3}$ level of $\mathrm{Ta}_{2} \mathrm{Cl}_{4}\left(\mathrm{PH}_{3}\right)_{4} \mathrm{H}_{4}$. The most striking change can be seen in the splitting of the $\pi$-levels. In the $(\mu-\mathrm{H})_{4}$ dimer, we have two equivalent $\mathrm{TaH}_{2} \mathrm{Ta} \pi$ interactions. Removal of a pair of trans bydrides

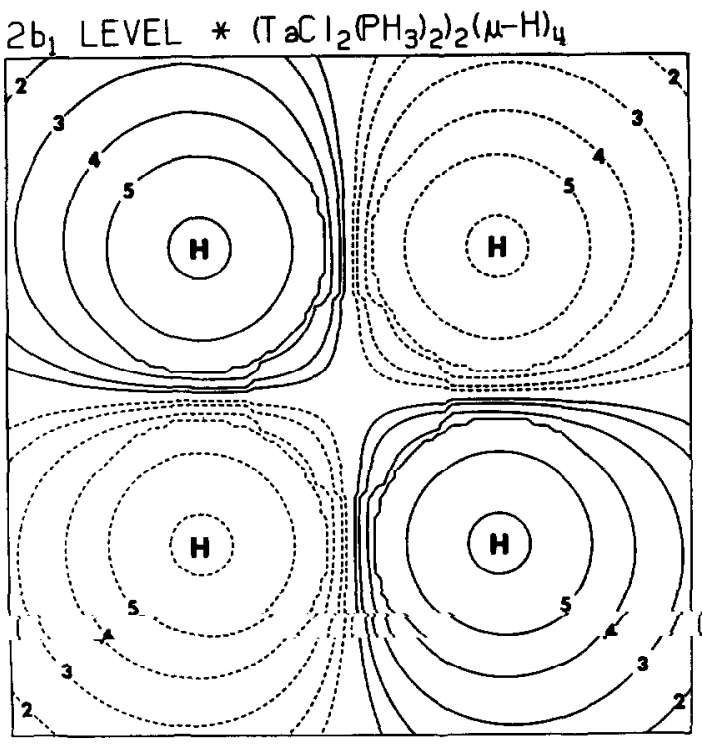

Fig. 9. Cross-section of the $2 b_{1}$ level ( $\mathrm{Ta}-\mathrm{H} \delta$-interaction) of $\mathrm{Ta}_{2} \mathrm{Cl}_{4}\left(\mathrm{PH}_{3}\right)_{4} \mathrm{H}_{4}$, through the four bridging hydride ligands.

from the bridge leaves us with only one and a pair of tantalum $5 d_{ \pm 1}$ orbitals which overlap to form a weak metal-metal $\pi$-bond. The Ta-Ta $\pi$-bonding level $\left[9 b_{3}\right.$ (Fig. 11)] is the HOMO of $\mathrm{Ta}_{2} \mathrm{Cl}_{4}\left(\mathrm{PH}_{3}\right)_{4} \mathrm{H}_{2}$, lying slightly above the $\mathrm{Ta}-\mathrm{Ta}$ $\sigma$-bonding $10 a$ level. Finally, we note that the bridge hydrogens of $\mathrm{Ta}_{2} \mathrm{Cl}_{4}\left(\mathrm{PH}_{3}\right)_{4} \mathrm{H}_{2}$ no longer possess a representation of $\delta$-symmetry and, consequently, there is no $\mathrm{TaH}_{2} \mathrm{Ta} \delta$-interaction. The $\delta$-level $\left(2 b_{1}\right)$ of $\mathrm{Ta}_{2} \mathrm{Cl}_{4}\left(\mathrm{PH}_{3}\right)_{4} \mathrm{H}_{4}$ becomes the LUMO $\left(9 b_{1}\right)$ of $\mathrm{Ta}_{2} \mathrm{Cl}_{4}\left(\mathrm{PH}_{3}\right)_{4} \mathrm{H}_{2}$ and loses all of its hydride character. It is now the (virtual) metal-metal $\delta$-bonding level. The loss of a $\delta$-interaction involving the bridge hydrogens removes the electronic barrier to hydride rotation which was indicated for the $(\mu-$ $\mathrm{H})_{4}$ dimers (vide supra). As a consequence, we expect the barrier for $(\mu-\mathrm{H})_{2}$ rotation about the Ta-Ta axis of 3 to be lower in energy than the harrier for $(\mu-\mathrm{H})_{4}$ rotation about the $\mathrm{Ta}-\mathrm{Ta}$ axis of 5 . The nroton NMB spestrum of $\mathrm{Ta}_{2} \mathrm{Cl}_{4}\left(\mathrm{PMS}_{3}\right)_{4} \mathrm{H}_{Z}$ (Fig. 3) and our inahility to effest hydride magnetic nonequivalence in the temperature range -90 to $+25^{\circ} \mathrm{C}$ are consistent with this hypothesis and indicate that the barriers differ by at least $10 \mathrm{kcal}$ $\mathrm{mol}^{-1}$.

\section{DISCUSSION}

The preparation of metal-metal-bonded niobium(III) and tantalum(III) dimers by sodium amalgam reduction of higher-valent halides or their complexes has ample precedent. The synthesis of 
A. J. SCIOLY et al.

Table 6. MS-X $\alpha$ Eigenvalues (including relativistic corrections) for $\mathrm{Ta}_{2} \mathrm{Cl}_{4}\left(\mathrm{PH}_{3}\right)_{4} \mathrm{H}_{2}{ }^{a}$

\begin{tabular}{|c|c|c|c|c|c|c|c|c|c|c|c|c|c|}
\hline \multirow[b]{2}{*}{ Level } & \multirow{2}{*}{$\begin{array}{c}\text { Energy } \\
\text { (EV) }\end{array}$} & \multicolumn{8}{|c|}{$\%$ Contribution } & & & & \\
\hline & & $\mathrm{Ta}$ & $\mathrm{Cl}$ & $P$ & HI & $\mathrm{H} 2$ & H3 & Int & Out & \multicolumn{4}{|c|}{ Ta angular contributions } \\
\hline $11 b_{1}$ & -1.022 & 36 & 9 & 6 & 5 & 0 & 0 & 38 & 7 & $98 \% \mathrm{D}$ & $2 \% \mathrm{~F}$ & & \\
\hline $10 b_{3}$ & -1.056 & 13 & 2 & 10 & 4 & 2 & 0 & 60 & 9 & $1 \% \mathrm{P}$ & $98 \% \mathrm{D}$ & $1 \% \mathrm{~F}$ & \\
\hline $10 b_{2}$ & -1.056 & 14 & 2 & 10 & 4 & 2 & 0 & 59 & 9 & $1 \% \mathrm{P}$ & $98 \% \mathrm{D}$ & $1 \% \mathrm{~F}$ & \\
\hline $10 b_{1}$ & -1.397 & 65 & 6 & 0 & 0 & 0 & 0 & 28 & 1 & $7 \% \mathrm{P}$ & $91 \% \mathrm{D}$ & $1 \% \mathrm{~F}$ & \\
\hline $12 a$ & -1.635 & 7 & 1 & 11 & 5 & 1 & 1 & 66 & 9 & & & & \\
\hline $11 a$ & -2.410 & 59 & 8 & 3 & 0 & 1 & 2 & 25 & 1 & $2 \% S$ & $4 \% \mathrm{P}$ & $92 \% \mathrm{D}$ & $1 \% \mathrm{~F}$ \\
\hline $9 b_{1}$ & -2.671 & 82 & 4 & 0 & 1 & 0 & $\mathbf{0}$ & 13 & 0 & $100 \% \mathrm{D}$ & & & \\
\hline $9 b_{3}$ & -4.277 & 58 & 4 & 12 & 0 & 1 & 0 & 25 & 1 & $9 \% \mathrm{P}$ & $90 \% \mathrm{D}$ & $1 \% \mathrm{~F}$ & \\
\hline $10 a$ & -4.947 & 70 & 8 & 3 & 0 & 0 & 6 & 12 & 0 & $5 \% \mathrm{~S}$ & $91 \% \mathrm{D}$ & $3 \% \mathrm{~F}$ & \\
\hline $9 b_{2}$ & -5.496 & 11 & 5 & 55 & 0 & 0 & 0 & 26 & 1 & $41 \% \mathrm{P}$ & $55 \% \mathrm{D}$ & $5 \% \mathrm{~F}$ & \\
\hline $8 b_{3}$ & -5.620 & 22 & 7 & 46 & 0 & 0 & 0 & 23 & 1 & $12 \% \mathrm{P}$ & $85 \% \mathrm{D}$ & $3 \% \mathrm{~F}$ & \\
\hline $9 a$ & -6.697 & 35 & 1 & 43 & 2 & 0 & 0 & 19 & 1 & $4 \% S$ & $4 \% \mathrm{P}$ & $92 \% \mathrm{D}$ & $1 \% \mathrm{~F}$ \\
\hline $8 b_{1}$ & -6.821 & 27 & 2 & 46 & 2 & 0 & 0 & 23 & 1 & $20 \% \mathrm{~S}$ & $1 \% \mathrm{P}$ & $79 \% \mathrm{D}$ & $1 \% \mathrm{~F}$ \\
\hline $8 b_{2}$ & -8.344 & 2 & 82 & 0 & 0 & 0 & 2 & 14 & 0 & & & & \\
\hline $8 a$ & -8.385 & 4 & 79 & 1 & 2 & 0 & 1 & 13 & 0 & & & & \\
\hline $7 b_{3}$ & -8.447 & 1 & 83 & 0 & 0 & 0 & 0 & 14 & 0 & & & & \\
\hline $7 b_{1}$ & -8.461 & 3 & 79 & 2 & 2 & 0 & 0 & 13 & 0 & & & & \\
\hline $7 b_{2}$ & -8.544 & 2 & 78 & 3 & 0 & 0 & 0 & 16 & 0 & & & & \\
\hline $6 b_{3}$ & -8.552 & 3 & 78 & 3 & 0 & 0 & 0 & 16 & 0 & & & & \\
\hline $6 b_{1}$ & -8.610 & 3 & 79 & 1 & 0 & 0 & 0 & 17 & 0 & & & & \\
\hline $7 a$ & -8.672 & 5 & 75 & 2 & 0 & 1 & 1 & 16 & 0 & & & & \\
\hline $6 b_{2}$ & -9.005 & 12 & 76 & 1 & 1 & 0 & 3 & 6 & 1 & $56 \% P$ & $40 \% \mathrm{D}$ & $4 \% \mathrm{~F}$ & \\
\hline $5 b_{3}$ & -9.271 & 17 & 76 & 0 & 0 & 0 & 0 & 6 & 0 & $18 \% \mathrm{P}$ & $79 \% \mathrm{D}$ & $2 \% \mathrm{~F}$ & \\
\hline $6 a$ & -9.330 & 24 & 62 & 1 & 1 & 0 & 8 & 2 & 1 & $19 \% \mathrm{P}$ & $77 \% \mathrm{D}$ & $4 \% \mathrm{~F}$ & \\
\hline $5 b_{1}$ & -9.879 & 18 & 75 & 0 & 0 & 0 & 0 & 6 & 1 & $39 \% \mathrm{~S}$ & $5 \% \mathrm{P}$ & $53 \% \mathrm{D}$ & $3 \% \mathrm{~F}$ \\
\hline $5 b_{2}$ & -11.139 & 29 & 6 & 18 & 9 & 10 & 28 & 0 & 0 & $7 \% \mathrm{P}$ & $86 \%$ D & $7 \% \mathrm{~F}$ & \\
\hline $5 a^{2}$ & -11.297 & 27 & 14 & 19 & 13 & 7 & 20 & 0 & 0 & $57 \% \mathrm{~S}$ & $10 \% \mathrm{P}$ & $29 \% \mathrm{D}$ & $3 \% \mathrm{~F}$ \\
\hline $4 b_{3}$ & -12.191 & 1 & 0 & 47 & 21 & 31 & 0 & 0 & 1 & & & & \\
\hline $4 b_{1}$ & -12.202 & 1 & 0 & 47 & 16 & 35 & 0 & 0 & 1 & & & & \\
\hline $4 b_{2}$ & -12.255 & 1 & 1 & 47 & 36 & 14 & 1 & 0 & 0 & & & & \\
\hline $3 b_{i}$ & -12.393 & 1 & 2 & 47 & 51 & 0 & 0 & 0 & 0 & & & & \\
\hline $3 b_{3}$ & -12.415 & 0 & 1 & 47 & 48 & 4 & 0 & 0 & 0 & & & & \\
\hline $4 a$ & -12.461 & 2 & 1 & 45 & 28 & 21 & 1 & 1 & 1 & & & & \\
\hline $3 b_{2}$ & -12.943 & 13 & 1 & 30 & 22 & 12 & 18 & 4 & 0 & $20 \% \mathrm{P}$ & $75 \% \mathrm{D}$ & $5 \% \mathrm{~F}$ & \\
\hline $3 a^{2}$ & -13.092 & 13 & 3 & 30 & 25 & 8 & 16 & 5 & 0 & $47 \% \mathrm{~S}$ & $17 \% \mathrm{P}$ & $33 \%$ D & $4 \% \mathrm{~F}$ \\
\hline
\end{tabular}

${ }^{a}$ See footnote to Table 5 . The HOMO is $9 b_{3}$.
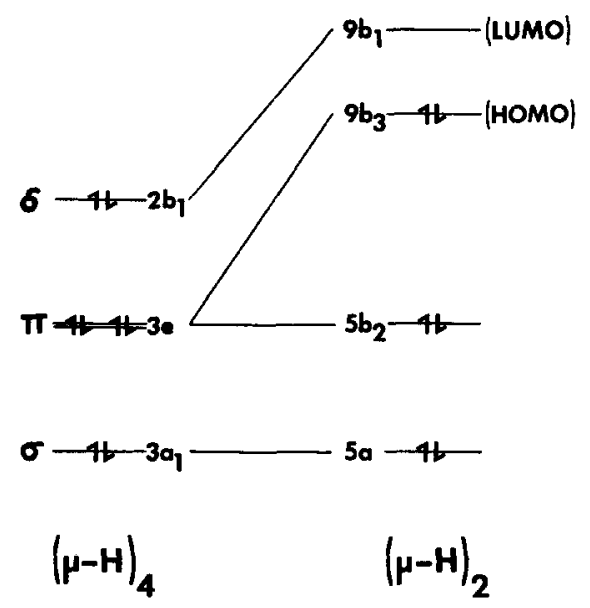

Fig. 10. Schematic correlation diagram uniting the Ta-H interactions in the $(\mu-\mathrm{H})_{4}$ and $(\mu-\mathrm{H})_{2}$ dimers.

$\mathrm{Ta}_{2} \mathrm{Cl}_{6}\left(\mathrm{PMe}_{3}\right)_{4}$ from $\mathrm{TaCl}_{5}$ was mentioned in the Introduction, but the approach is due to Maas and McCarley. ${ }^{22}$ In 1973, these authors prepared a series of $\mathrm{Nb}_{2} \mathrm{X}_{6}(\mathrm{THT})_{3}$ complexes $(\mathrm{X}=\mathrm{Cl}$, Br or I;
$9 b_{3}$ LEVEL * $\left(\mathrm{TaCl}_{2}\left(\mathrm{PH}_{3}\right)_{2}\right)_{2}\left(\mu-\mathrm{H}_{2}\right.$

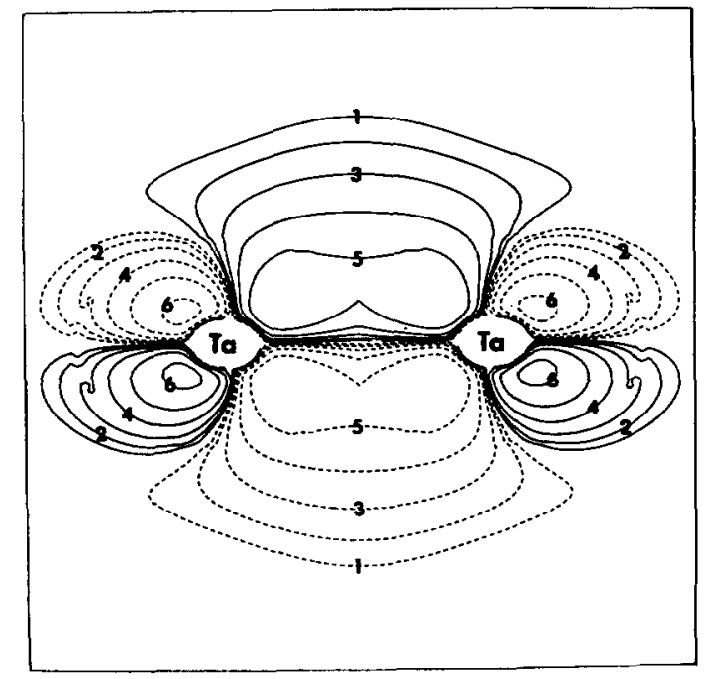

Fig. 11. Cross-section of the $9 b_{3}$ level (HOMO) of $\mathrm{Ta}_{2} \mathrm{Cl}_{4}\left(\mathrm{PH}_{3}\right)_{4} \mathrm{H}_{2}$. 
THT $=$ tetrahydrothiophene) by $\mathrm{Na}-\mathrm{Hg}$ reduction of $\mathrm{NbX}_{4}(\mathrm{THT})_{2}$ in benzene. The synthesis of 3 reported here is novel only in the sense that precursor $\mathbf{2}$ is a well-defined, metal-metal-bonded tantalum(IV) dimer. The structure of 3 , on the other hand, is unprecedented in niobium(III) or tantalum(III) dimer chemistry. The chloro-bridged species, 1 and $\mathrm{Ta}_{2} \mathrm{Cl}_{6}$ (dmpe) ${ }_{2},{ }^{23}$ adopt edge-sharing bioctahedral geometries while the $\mathrm{M}_{2} \mathrm{X}_{6}\left(\mathrm{SR}_{2}\right)_{3}$ dimers prefer confacial bioctahedral structures. ${ }^{24}$

We can understand the structure of 3 in terms of the following hypothetical transformation. Replacement of the bridging halogens in 1 with smaller hydride ligands must shorten the $\mathrm{Ta}-\mathrm{Ta}$ separation because effective $\mathrm{Ta}-\mathrm{H}$ bonding requires that the metals be brought into closer proximity to each other. This, in turn, forces the terminal ligands into pyramidal arrangements to relieve axial-axial interactions. In addition, replacement of the chlorides destroys the $\delta$-interaction shown below, which locks 1 into the edge-sharing geometry. Recall that the hydride ligands in 3 do not possess a representation with $\delta$-symmetry and, therefore, are not constrained to a specific location about the $\mathrm{Ta}-\mathrm{Ta}$ axis.

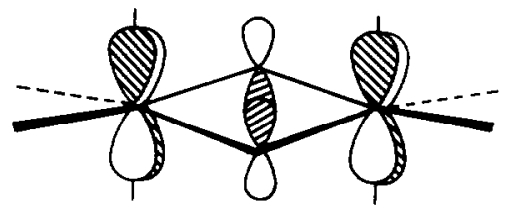

Dimer 3 is the only metal-metal multiply bonded system which reacts readily and cleanly with $\mathrm{Cl}_{2}$, $\mathrm{HCl}$ and $\mathrm{H}_{2} .{ }^{*}$ These substrates add across the $\mathrm{Ta}=\mathrm{Ta}$ bond, decreasing the bond order from two to one, and there are none of the gross structural rearrangements which usually accompany oxidative-addition reactions in metal-metal-bonded complexes. $^{26}$ Our observation that only the $C_{s}$ isomer of $\mathbf{2}$ is formed in the chlorination reaction also suggests that the addition of $X_{2}$ to 3 is a concerted process.

The X-ray structure of dimer 5 confirms that $\mathrm{H}_{2}$ addition is across the Ta-Ta bond of 3 and also shows the combined effect of four strong $\mathrm{Ta}-\mathrm{H}-\mathrm{Ta}$ interactions on the Ta-Ta separation. The $\mathrm{Ta}-\mathrm{Ta}$ bond length in $\mathrm{S}$ is $\mathrm{ca} 0.03 \AA$ shorter than found in 3 , where we have no $\delta$-interaction and only one $\pi$-type $\mathrm{TaH}_{2} \mathrm{Ta}$ interaction.

The electronic structure calculations on $\mathrm{Ta}_{2} \mathrm{Cl}_{4}$ -

${ }^{*}$ The $\mathrm{Mo}^{3} \mathrm{Mo}$ bond of $\left[\mathrm{CpMo}(\mathrm{CO})_{2}\right]_{2}$ will add $\mathrm{Hl}$ and $\mathrm{I}_{2}$ thermally but not $\mathrm{H}_{2}{ }^{25}$
$\left(\mathrm{PH}_{3}\right)_{4} \mathrm{H}_{4}$ and $\mathrm{Ta}_{2} \mathrm{Cl}_{4}\left(\mathrm{PH}_{3}\right)_{4} \mathrm{H}_{2}$ complement our structural and spectroscopic studies on 3 and 5 . We now have some appreciation of the electronic factors which influence hydride rotation in these systems, and the calculations support the assignments of Ta-Ta bond orders in 3 and 5 . The MS$X \alpha$ results can also be used to interpret the optical spectra of 3 and 5 , but this is another story and one which we will relate in a future paper in this series.

The synthesis of $\mathbf{3}$ and $\mathbf{5}$ naturally call for a comment on the possible existence of $\mathrm{Ta}_{2} \mathrm{Cl}_{4}$ $\left(\mathrm{PMe}_{3}\right)_{4}$, since the $(\mu-\mathrm{H})_{2}$ and $(\mu-\mathrm{H})_{4}$ complexes are the sequential hydrogenation products of this tantalum(II) dimer. $A$ priori, we have no reason to believe that $\mathrm{Ta}_{2} \mathrm{Cl}_{4}\left(\mathrm{PMe}_{3}\right)_{4}$ should not exist and efforts to prepare it, or an analogue, continue in our laboratory at Los Alamos. Neither reduction of 1 nor thermolysis of trans- $\mathrm{TaCl}_{2}\left(\mathrm{PMe}_{3}\right)_{4}{ }^{27} \uparrow$ have yielded this dimer, but there are other possibilities which merit investigation, e.g. thermally induced reductive elimination of $\mathrm{H}_{2}$ from 3 , and these are being pursued.

We would be remiss not to mention the recent success of the Cotton group ${ }^{28}$ in preparing and structurally characterizing the face-sharing bioctahedral tantalum(II) dimer, $\left[\mathrm{Ta}_{2} \mathrm{Cl}_{6}(\mu-\mathrm{THT})_{3}\right]^{2}$. The isolation of this material, which contains a formal metal-metal triple bond [Ta-Ta 2.626(1) $\AA$ ], provides further impetus in the search for molecules containing unbridged Ta-Ta triple bonds.

\section{EXPERIMENTAL}

\section{Reagents}

Tantalum pentachloride was purchased from Pressure Chemical and sublimed under high vacuum to remove nonvolatile impurities. $\mathrm{Ta}_{2} \mathrm{Cl}_{6}\left(\mathrm{PMe}_{3}\right)_{4} \mathrm{H}_{2}, \quad \mathrm{Ta}_{2} \mathrm{Cl}_{6}\left(\mathrm{PMe}_{3}\right)_{4} \mathrm{D}_{2}$ and $\mathrm{TaCl}_{2} \mathrm{H}_{2}\left(\mathrm{PMe}_{3}\right)_{4}$ were prepared and purified by literature procedures. ${ }^{5,13}$ Hydrogen (Air products, 99.995\%) and deuterium (Linde, 99.5\%) were used as received. Chlorine and hydrogen chloride (both from Matheson) were dried by passage through concentrated sulfuric acid.

THF, ether and glyme were dried and freed from dissolved molecular oxygen by distillation under argon from a solution of the solvent, benzophenone, and sodium or potassium. $n$-Hexane was purified

†Thermolysis of trans- $\mathrm{TaCl}_{2}\left(\mathrm{PMe}_{3}\right)_{4}$ in refluxing cyclohexane leads to disproportionation and hydride abstraction from the solvent. ${ }^{27(b)}$ 
by stirring over saturated $\mathrm{KMnO}_{4}$ in $10 \%$ sulfuric acid $(2 \times 6 \mathrm{~h})$. It was then sequentially washed with water, saturated aqueous $\mathrm{Na}_{2} \mathrm{CO}_{3}$ and water, dried over $\mathrm{MgSO}_{4}$, filtered and distilled under argon from sodium-potassium alloy.

\section{Physical and analytical measurements}

Elemental analyses and molecular-weight measurẹments were performed by Galbraith Laboratories, Knoxville, TN.

IR spectral measurements were made on a Perkin-Elmer Model 1330 spectrometer. Samples were run as $\mathrm{KBr}$ discs. NMR spectra were run on Bruker WM-360 and JEOL FX90Q spectrometers. ${ }^{31} \mathrm{P}$ spectra were recorded at 36.20 or $145.80 \mathrm{MHz}$, and ${ }^{1} \mathrm{H}$ spectra at $360.1 \mathrm{MHz}$. Benzene- $d_{6}$ was used as a lock solvent for most spectra. Phosphorus chemical shifts $(\delta)$ are reported relative to external $85 \%$ aqueous $\mathrm{H}_{3} \mathrm{PO}_{4}$. Negative chemical shifts are assigned to resonances at lower frequency (higher field) than the reference.

\section{General synthetic procedures}

Manipulations of air-sensitive reagents and solutions and the workup of reaction products were usually performed within the confines of a heliumfilled Vacuum Atmospheres Dri-Lab (HE-43). The latter is equipped with a high capacity Dri-Train (MO-40V), and a Dri-Cold Freezer maintained at $-40^{\circ} \mathrm{C}$.

\section{$\mathrm{Ta}_{2} \mathrm{Cl}_{4}\left(\mathrm{PMe}_{3}\right)_{4} \mathrm{H}_{2}(3)$}

Inside the drybox, $\mathrm{Ta}_{2} \mathrm{Cl}_{6}\left(\mathrm{PMe}_{3}\right)_{4} \mathrm{H}_{2}(3.0 \mathrm{~g}$, $3.41 \mathrm{mmol}$ ) was added to $150 \mathrm{~cm}^{3}$ of THF in a two-neck, $250-\mathrm{cm}^{3}$ Morton flask, equipped with a mechanical stirrer and $\mathbf{N}_{2}$-gas inlet. Sodium amalgam $\left(2.5 \mathrm{~cm}^{3}\right.$ of $0.5 \%$ amalgam, $7.35 \mathrm{mmol}$ of $\mathrm{Na})$ and mercury $\left(8 \mathrm{~cm}^{3}\right)$ were added and the flask was. removed from the drybox. The flask was connected to a source of argon, cooled to $0^{\circ} \mathrm{C}$ in an ice-salt bath, and the reaction mixture was stirred vigorously for $4-5 \mathrm{~h}$. The yellow-green suspension turned dark green during this period. The flask was returned to the drybox, the contents were filtered through $\mathrm{ca} 1$ inch of Celite on a $60 \mathrm{~cm}^{3}$ medium porosity sintered glass frit, and the flask was rinsed with $50 \mathrm{~cm}^{3}$ of fresh THF. The combined filtrate was stripped to dryness and the solid residue was extracted with diethyl ether $\left(4 \times 50 \mathrm{~cm}^{3}\right)$. After filtration, the combined extracts were stripped to dryness, providing 3 as a dark green powder. Yield $2.01 \mathrm{~g}(73 \%)$.

An analytical sample was obtained by recrystal- lization from a concentrated ether solution at $-40^{\circ} \mathrm{C}$.

Calc. for $\mathrm{Ta}_{2} \mathrm{Cl}_{4}\left(\mathrm{PMe}_{3}\right)_{4} \mathrm{H}_{2}\left(\mathrm{C}_{12} \dot{\mathrm{H}}_{38} \mathrm{Cl}_{4} \mathrm{P}_{4} \mathrm{Ta}_{2}\right)$ : C, $17.8 ; \mathrm{H}, 4.7 ; \mathrm{Cl}, 17.5 \% ; M_{r}, 810$. Found: C, 17.8; $\mathrm{H}, 4.7 ; \mathrm{Cl}, 17.8 \% ; M_{r}, 813$.

IR $\left(\mathrm{cm}^{-1}\right): 1232\left(\mathrm{~m}, v_{\mathrm{Ta}-\mathrm{H}-\mathrm{Ta}_{\mathrm{a}}}\right)$.

${ }^{1} \mathrm{H}$ NMR (ppm, $\mathrm{C}_{6} \mathrm{D}_{6}$ ): 8.52 (quin, 2, $J_{\mathrm{PH}}=$ $\left.13.4 \mathrm{~Hz}, H_{\mathrm{b}}\right), 1.52\left[\mathrm{t}, 36, J_{\mathrm{PH}}=3.8 \mathrm{~Hz}, \mathrm{P}\left(\mathrm{CH}_{3}\right)_{3}\right]$.

${ }^{31} \mathrm{P}$ NMR (ppm, $\mathrm{C}_{6} \mathrm{D}_{6}$, selective $\left\{{ }^{1} \mathrm{H}\right\}$ at 1.52 ): $+1.3\left(\mathrm{t}, J_{\mathrm{PH}}=13.4 \mathrm{~Hz}\right)$

The deuteride, $\mathrm{Ta}_{2} \mathrm{Cl}_{4}\left(\mathrm{PMe}_{3}\right)_{4} \mathrm{D}_{2}$, was prepared from $\mathrm{Ta}_{2} \mathrm{Cl}_{6}\left(\mathrm{PMe}_{3}\right)_{4} \mathrm{D}_{2}$ in a similar fashion. IR $\left(\mathrm{cm}^{-1}\right): 860\left(v_{\mathrm{Ta}-\mathrm{D}-\mathrm{Ta}}\right)$.

\section{$\mathrm{Ta}_{2} \mathrm{Cl}_{6}\left(\mathrm{PMe}_{3}\right)_{4} \mathrm{H}_{2}(2)$ from 3}

A $0.25 \mathrm{~g}(0.31 \mathrm{mmol})$ sample of 3 was dissolved in $30 \mathrm{~cm}^{2}$ of ether in a $100-\mathrm{cm}^{3}$ Schlenk flask equipped with a $\mathrm{N}_{2}$-gas inlet, pressure-equalizing dropping funnel and a magnetic stir bar. The solution was cooled to $-20^{\circ} \mathrm{C}$ in a dry ice-acetone bath and $30 \mathrm{~cm}^{3}$ of a $0.01 \mathrm{M} \mathrm{Cl}_{2}$-ether solution was added dropwise over the course of $0.5 \mathrm{~h}$. A light green powder precipitated during the addition. The suspension was stirred for an additional $0.5 \mathrm{~h}$ at $-20^{\circ} \mathrm{C}$. Approximately half the ether was removed in vacuo and the solid was collected by filtration, washed with hexane $\left(2 \times 10 \mathrm{~cm}^{3}\right)$ and dried. Yield $0.91 \mathrm{~g}$ $(70 \%)$. The spectroscopic properties (NMR and IR) of this material were identical to those reported for 2. ${ }^{5}$ The filtrate was stripped to dryness and checked by NMR. 2 and a trace of unreacted 3 were the only materials detected.

$$
\mathrm{Ta}_{2} \mathrm{Cl}_{5}\left(\mathrm{PMe}_{3}\right)_{4} \mathrm{H}_{3} \text { (4) }
$$

A $0.60-\mathrm{g}(0.74-\mathrm{mmol})$ sample of 3 was dissolved in $40 \mathrm{~cm}$ of ether in a $100-\mathrm{cm}^{3}$ Schlenk flask, equipped as noted above. The solution was cooled to $-20^{\circ} \mathrm{C}$ and $30 \mathrm{~cm}^{3}$ of a $0.025 \mathrm{M} \mathrm{HCl}$-ether solution was added dropwise over the course of $0.5 \mathrm{~h}$. A light green solid precipitated during the addition. When the latter was complete, the reaction mixture was stirred for an additional $0.5 \mathrm{~h}$ at $-20^{\circ} \mathrm{C}$. Half of the ether was then removed in vacuo and the suspension was cooled to $-40^{\circ} \mathrm{C}$ for several hours. The product was filtered, washed with hexane $\left(2 \times 10 \mathrm{~cm}^{3}\right)$ and dried in vacuo. Yield $0.45 \mathrm{~g}(72 \%)$. An analytical sample was obtained by recrystallization from ether at $-40^{\circ} \mathrm{C}$.

Calc. for $\mathrm{Ta}_{2} \mathrm{Cl}_{5}\left(\mathrm{PMe}_{3}\right)_{4} \mathrm{H}_{3}\left(\mathrm{C}_{12} \mathrm{H}_{39} \mathrm{Cl}_{5} \mathrm{P}_{4} \mathrm{Ta}_{2}\right)$ : $\mathrm{C}, 17.0 ; \mathrm{H}, 4.6 ; \mathrm{Cl}, 20.9 \% ; M_{r}, 846.5$. Found: $\mathrm{C}, 16.9$; $\mathrm{H}, 4.6 ; \mathrm{Cl}, 21.0 \% ; M_{r}, 853$.

IR( $\left.\mathrm{cm}^{-1}\right): 1260\left(\mathrm{~m}, v_{\mathrm{Ta}-\mathrm{H}-\mathrm{Ta}}\right)$.

${ }^{1} \mathrm{H}$ NMR (ppm, $\mathrm{C}_{6} \mathrm{D}_{6}$ ): 9.68 (complex m, 1, $\mathrm{H}_{\mathrm{b}}$ ), 7.69 (complex m, $\left.2, H_{\mathrm{b}}^{\prime}\right), 1.60\left[\mathrm{~d}, 18, J_{\mathrm{PH}}=9.3 \mathrm{~Hz}\right.$, 
$\left.\mathrm{P}\left(\mathrm{CH}_{3}\right)_{3}\right], 1.29\left[\mathrm{~d}, 18, \mathrm{~J}_{\mathrm{PH}}=8.8 \mathrm{~Hz}, \mathrm{P}^{\prime}\left(\mathrm{CH}_{3}\right)_{3}\right]$.

${ }^{31} \mathrm{P}$ NMR (ppm, $\left.\mathrm{C}_{6} \mathrm{D}_{6},\left\{{ }^{1} \mathrm{H}\right\}\right):+8.45[\mathrm{~m}, 1$, $\left.\mathrm{P}\left(\mathrm{CH}_{3}\right)_{3}, J_{\mathrm{AX}}+J_{\mathrm{AX}^{\prime}}=28.7 \mathrm{~Hz}\right],-13.34[\mathrm{~m}, 1$, $\left.\mathrm{P}^{\prime}\left(\mathrm{CH}_{3}\right)_{3}, J_{\mathrm{AX}}+J_{\mathrm{AX}^{\prime}}=28.7 \mathrm{~Hz}\right]$.

\section{$\mathrm{Ta}_{2} \mathrm{Cl}_{4}\left(\mathrm{PMe}_{3}\right)_{4} \mathrm{H}_{4}$ (5)}

Method A. A 1.00-g sample of 3 was dissolved in $50 \mathrm{~cm}^{3}$ of ether in a $90-\mathrm{cm}^{3}$ Fischer-Porter pressure vessel. The latter was sealed, removed from the drybox, and connected to a source of hydrogen and vacuum. The bomb was evacuated and back-filled with $\mathrm{H}_{2}$ ( 40 psi). After $12 \mathrm{~h}$, the bomb was vented, returned to the drybox and half the ether was removed in vacuo. The light green suspension was cooled to $-40^{\circ} \mathrm{C}$ for several hours. The product was filtered off, washed with hexane $\left(2 \times 10 \mathrm{~cm}^{3}\right)$ and dried in vacuo. Yield $0.85 \mathrm{~g}(85 \%)$. An analytical sample was obtained by recrystallization from ether at $-40^{\circ} \mathrm{C}$.

Calc. for $\mathrm{Ta}_{2} \mathrm{Cl}_{4}\left(\mathrm{PMe}_{3}\right)_{4} \mathrm{H}_{4}\left(\mathrm{C}_{12} \mathrm{H}_{40} \mathrm{Cl}_{4} \mathrm{P}_{4} \mathrm{Ta}_{2}\right)$ : C, $17.8 ; \mathrm{H}, 5.0 ; \mathrm{Cl}, 17.5 \% ; M_{r}, 812$. Found: C, 17.6; $\mathrm{H}, 5.0 ; \mathrm{Cl}, 17.4 \% ; M_{r}, 799$.

IR $\left(\mathrm{cm}^{-1}\right): 1225\left(\mathrm{~m}, v_{\mathrm{Ta}-\mathrm{H}-\mathrm{Ta}}\right)$.

${ }^{1} \mathrm{H}$ NMR (ppm, $\left.\mathrm{C}_{6} \mathrm{D}_{6}\right): 8.79\left(\mathrm{~m}, 4, H_{\mathrm{b}}\right), 1.47[\mathrm{t}$, $\left.36, J_{\mathrm{HP}}=4 \mathrm{~Hz}, \mathrm{P}\left(\mathrm{CH}_{3}\right)_{3}\right]$.

${ }^{31} \mathrm{P}$ NMR (ppm, $\left.\mathrm{C}_{6} \mathrm{D}_{6},\left\{{ }^{1} \mathrm{H}\right\}\right):-1.8(\mathrm{~s})$.

Method B. A freshly recrystallized sample of 6 $(2.0 \mathrm{~g}, 2.6 \mathrm{mmol})$ was transferred to a $100-\mathrm{cm}^{3}$ Schlenk flask containing $c a 40 \mathrm{~cm}^{3}$ of methylcyclohexane. The flask was fitted with a reflux condenser and the red suspension was heated at reflux $\left(101^{\circ} \mathrm{C}\right)$ for $2 \mathrm{~h}$ under a slow argon flush. Over the course of the thermolysis, the color of the suspension turned pale green. The suspension was then cooled to $-40^{\circ} \mathrm{C}$ for several hours, filtered, and the product was washed with hexane $\left(2 \times 5 \mathrm{~cm}^{3}\right)$ and dried in vacuo. Yield $1.3 \mathrm{~g}(89 \%)$. The purity of 5 synthesized by this route should be checked by proton NMR. If any 3 is detected, the entire yield is placed in a $90 \mathrm{~cm}^{3}$ Fischer-Porter pressure vessel together with $20 \mathrm{~cm}^{3}$ of ether and the vessel is pressurized (40 psi) with $\mathrm{H}_{2}$ for several hours. The pure product is then isolated by removal of the solvent in vacuo.

\section{$X$-ray structure determinations}

General procedures were the same as those described previously. ${ }^{29}$

$\mathrm{Ta}_{2} \mathrm{Cl}_{4}\left(\mathrm{PMe}_{3}\right)_{4} \mathrm{H}_{2}$. Crystals of 3 were grown by slow cooling of concentrated glyme solutions. The bulk sample consisted of well-formed green-black crystals of various sizes. Attempts to use the smaller crystals for data collection were unsuccessful; omega scans were in excess of $2^{\circ}$. Several of the larger crystals were then fractured and examined.
In most cases twinning occurred, yielding cells with equivalent $a$ - and $c$-axes, and considerable peak splitting. After numerous attempts, an irregularlyshaped fragment of maximum dimension $0.06 \mathrm{~mm}$ was obtained which was not twinned, and data were collected using it. The sample manipulation and mounting were performed in a nitrogen-filled glove bag and the sample was transferred to the goniostat (under $\mathrm{N}_{2}$ ) and cooled to $-160^{\circ} \mathrm{C}$ for characterization and data collection (see supplementary data).

The structure was solved by a combination of direct methods, Patterson techniques, and difference Fourier techniques, and refined by full-matrix least squares. All nonhydrogen atoms were located, and their positional and thermal parameters (anisotropic) refined. The molecule lies on a crystallographic two-fold axis and no disorder is apparent in the nonhydrogen positions. Hydrogen atoms, excluding the bridging hydride, were located in a difference Fourier synthesis and refined isotropically. Several of the hydrogen thermal parameters are rather large, and the distances and angles involving the methyl hydrogens indicate they are poorly located.

A final difference Fourier indicated several peaks of density between 0.8 and $2.1 e \AA^{-3}$. While one of these peaks was located in the bridge region, there was sufficient doubt as to preclude its inclusion in the refinement.

$\mathrm{Ta}_{2} \mathrm{Cl}_{4}\left(\mathrm{PMe}_{3}\right)_{4} \mathrm{H}_{4}$. Crystals of 5 were grown by slow cooling of concentrated THF solutions. Inside a nitrogen-filled glove bag, a green block was mounted on a glass fiber, and then transferred to the goniostat where it was cooled to $-165^{\circ} \mathrm{C}$. The structure was solved by Patterson and Fourier techniques, and refined by full-matrix least squares. The data were corrected for the effects of absorption. All nonhydrogen atoms were located and their positional and anisotropic thermal parameters refined. A difference Fourier synthesis, phased on the nonhydrogen atom parameters, revealed peaks which could be assigned as the hydrogens. When all of these were included in the refinement, two of the methyl group hydrogens failed to converge. For this reason, all methyl hydrogens were placed in fixed positions and only the bridging hydrogen was refined. A final difference Fourier map was essentially featureless, the largest peaks being $c a$ $0.6 e \AA^{-3}$, located near the tantalum and chlorine atoms. Crystal data are given in Table 7.

\section{Calculations}

The multiple-scattering $\mathrm{X} \alpha$ method was applied to the model compounds $\mathrm{Ta}_{2} \mathrm{Cl}_{4}\left(\mathrm{PH}_{3}\right)_{4} \mathrm{H}_{2}$ and $\mathrm{Ta}_{2} \mathrm{Cl}_{4}\left(\mathrm{PH}_{3}\right)_{4} \mathrm{H}_{4}$. Values of $\alpha$ were taken from 
Table 7. Crystal data for $\mathrm{Ta}_{2} \mathrm{Cl}_{4}\left(\mathrm{PMe}_{3}\right)_{4} \mathrm{H}_{2}$ and $\mathrm{Ta}_{2} \mathrm{Cl}_{4}\left(\mathrm{PMe}_{3}\right)_{4} \mathrm{H}_{4}$

\begin{tabular}{|c|c|c|}
\hline & 3 & 5 \\
\hline $\begin{array}{l}\text { mol formula } \\
\text { color } \\
\text { crystal dimens, } \mathrm{mm} \\
\text { space group } \\
\text { temp, }{ }^{\circ} \mathrm{C} \\
\text { cell dimens }\end{array}$ & $\begin{array}{l}\mathrm{Ta}_{2} \mathrm{CI}_{4} \mathrm{P}_{4} \mathrm{C}_{12} \mathrm{H}_{38} \\
\text { green-black } \\
0.06 \times 0.06 \times 0.05 \\
\mathrm{C} 2 / \mathrm{c} \\
-161\end{array}$ & $\begin{array}{l}\mathrm{Ta}_{2} \mathrm{CI}_{4} \mathrm{P}_{4} \mathrm{C}_{12} \mathrm{H}_{38} \\
\text { green } \\
0.06 \times 0.06 \times 0.07 \\
\mathrm{P} 4 / \mathrm{nbm} \\
-165\end{array}$ \\
\hline$a, \AA$ & $18.371(5)$ & $12.579(2)$ \\
\hline$b, \AA$ & $9.520(3)$ & $12.579(2)$ \\
\hline$c, \AA$ & $18.942(6)$ & $10.205(2)$ \\
\hline$\beta, \operatorname{deg}$ & $125.36(2)$ & 90.00 \\
\hline molecules/cell & 4 & 2 \\
\hline$d$ (calcd), $\mathrm{g} \mathrm{cm}^{-3}$ & 1.991 & 1.670 \\
\hline wavelength, $\AA$ & 0.71069 & 0.71069 \\
\hline $\mathrm{mol} \mathrm{wt}$ & 810.04 & 812.06 \\
\hline linear abs coeff, $\mathrm{cm}^{-1}$ & 86.32 & 72.22 \\
\hline $\max a b s$ & - & 0.402 \\
\hline $\min a b s$ & - & 0.499 \\
\hline $\begin{array}{l}\text { diffractometer } \\
\text { mode }\end{array}$ & $\begin{array}{l}\text { Picker 4-circle } \\
\Theta-2 \Theta\end{array}$ & $\begin{array}{l}\text { Picker 4-circle } \\
\Theta-2 \Theta\end{array}$ \\
\hline $\begin{array}{l}2 \Theta \text { range, deg } \\
\text { quadrants collected } \\
\text { no. of data with }\end{array}$ & $\begin{array}{l}6-45 \\
+h,+k, \pm 1\end{array}$ & $\begin{array}{l}6-55 \\
+h,+k,+1\end{array}$ \\
\hline$F_{0} \geq 2.33 \sigma\left(F_{0}\right)$ & 2155 & 656 \\
\hline No. of unique data & 2399 & 897 \\
\hline $\begin{array}{l}\text { total data collected } \\
\text { final residuals }\end{array}$ & 2693 & 3474 \\
\hline $\mathbf{R}_{\mathbf{F}}$ & 0.0464 & 0.0512 \\
\hline $\mathbf{R}_{\mathbf{w F}}$ & 0.0475 & 0.0402 \\
\hline $\begin{array}{l}\text { goodness of fit, } \\
\text { last cycle }\end{array}$ & & \\
\hline $\max \Delta / \sigma$, last cycle & 0.05 & 0.5 \\
\hline
\end{tabular}

Schwartz, ${ }^{30}$ except for hydrogen $(\alpha=0.77725)^{31}$ and tantalum, whose $\alpha$ value was extrapolated from Schwartz as $0.69319 .^{32}$ For inter- and outer-sphere regions, values of $\alpha$ were calculated as valenceelectron weighted averages of the atomic $\alpha$ values.

The starting molecular potentials were a superposition of the Herman-Skillman atomic potentials $^{\mathbf{3 3}}$ of the neutral atoms. Atomic spheres were allowed to overlap in accordance with the scheme of Norman. ${ }^{34}$ The final radii were chosen as $89 \%$ of the atomic number radii. In each calculation, the outer sphere was chosen to be tangent to the outermost atomic sphere.

Coordinates were calculated using the crystallographic data for the individual trimethyl phosphine species. The bond distances and bond angles used for $\mathrm{Ta}_{2} \mathrm{Cl}_{4}\left(\mathrm{PH}_{3}\right)_{4} \mathrm{H}_{4}$ were: $\mathrm{Ta}-\mathrm{Ta}, 2.511 \AA ; \mathrm{Ta}-\mathrm{Cl}$, $2.461 \AA ; \mathrm{Ta}-\mathrm{P}, 2.604 \AA ; \mathrm{Ta}-\mathrm{H}, 1.81 \AA ; \mathrm{Ta}-\mathrm{Ta}-\mathrm{P}$, $110.3^{\circ}$; Ta-Ta-Cl, $121.6^{\circ}$; Ta-H-Ta, $88^{\circ} ; \mathrm{P}-\mathrm{H}$, $1.415 \AA ;$ Ta-P-H, $110.3^{\circ}$. The geometry was idealized to $D_{2 d}$-symmetry. The corresponding data for the $(\mu-\mathrm{H})_{2}$ dimer were: Ta-Ta, $2.545 \AA ; \mathrm{Ta}-\mathrm{Cl}$, $2.416 \AA ;$ Ta-P, $2.596 \AA ; \mathrm{Ta}-\mathrm{H}, 1.85 \AA ; \mathrm{Ta}-\mathrm{Ta}-\mathrm{P}$, $102^{\circ}$; Ta-Ta-Cl, $116^{\circ}$; Ta-H-Ta, $87^{\circ}$. The $\mathrm{PH}_{3}$ data were the same as given above and the geometry was idealized to $D_{2}$-symmetry.

The molecules were each placed in a coordinate system with its origin at the midpoint of the $\mathrm{Ta}-$ $\mathrm{Ta}$ bond, the $Z$-axis colinear with the Ta-Ta bond and the $X Z$ and $Y Z$ planes each chosen to include four terminal ligand atoms. Each $\mathrm{PH}_{3}$ ligand was oriented about the $\mathrm{Ta}-\mathrm{P}$ bond such that each distal hydrogen atom was in the $X Z$ or $Y Z$ plane.

Partial waves up to $l=0,2,2,3$ and 4 were used for $\mathrm{H}, \mathrm{P}, \mathrm{Cl}, \mathrm{Ta}$ and outer sphere, respectively.

For each molecule the calculation of the $\mathrm{X} \alpha$ eigenvalues was first carried out nonrelativistically, until consecutive values of the SCF potential differed by less than $0.001 \mathrm{Ry}$. Relativistic corrections, viz. Darwin and mass-velocity terms for both core and valence metal orbitals, ${ }^{21}$ were then added and the calculation was reconverged.

Acknowledgments-We are grateful to the National Science Foundation for support of this research and to Wrubel Computer Center, Indiana University, for a generous gift of computing time. AJS and APS would like to thank Professor B. E. Bursten (Ohio State) for helpful discussions on the MS-X $\alpha$ method.

\section{REFERENCES}

1. D. J. Santure and A. P. Sattelberger, Inorg. Chem. 1985, 24, 3477.

2. F. A. Cotton and R. A. Walton, Multiple Bonds between Metal Atoms. Wiley, New York (1982).

3. P. R. Sharp and R. R. Schrock, J. Am. Chem. Soc. $1980,102,1430$.

4. A. P. Sattelberger, R. B. Wilson, Jr and J. C. Huffman, Inorg. Chem. 1982, 21, 2392.

5. A. P. Sattelberger, R. B. Wilson, Jr and J. C. Huffman, Inorg. Chem. 1982, 21, 4179.

6. R. B. Wilson, Jr, J. C. Huffman and A. P. Sattelberger, J. Am. Chem. Soc. 1982, 104, 858.

7. A. P. Sattelberger, Inorganic Chemistry: Toward the 21st Century, ACS Symposium Series No. 211, p. 291. American Chemical Society, Washington D.C.(1983).

8. M. R. Churchill and S. W-Y. Chang, Inorg. Chem. 1974, 13, 2413.

9. M. J. Bennett, W. A. G. Graham, J. K. Hoyano and W. L. Hutcheon, J. Am. Chem. Soc. 1972, 94, 6232.

10. F. A. Cotton, M. W. Extine, T. R. Felthouse, B. W. S. Kolthammer and D. G. Lay, J. Am. Chem. Soc. 1981, 103, 4040.

11. A. Bino, F. A. Cotton, Z. Dori and J. C. Sekutowski, Inorg. Chem. 1978, 17, 2946.

12. (a) R. R. Schrock and J. D. Fellmann, personal communication; (b) J. D. Fellmann, Ph.D. thesis, Massachusetts Institute of Technology (1980).

13. M. L. Luetkens, Jr, W. L. Elcesser, J. C. Huffman and A. P. Sattelberger, Inorg. Chem. 1984, 23, 1718.

14. J. B. Raynor, A. P. Sattelberger and M. L. Luetkens, Jr, Inorg. Chim. Acta 1986, 113, 51.

15. (a) I. H. Elson, J. K. Kochi, U. Klubunde, G. Parshall and F. N. Tebbe, J. Am. Chem. Soc. 1974, 96, 7374; (b) I. H. Elson and J. K. Kochi, J. Am. Chem. Soc. 
1975, 97, 1263.

16. R. Bau, W. E. Carroll, D. W. Hart, R. G. Teller and T. F. Koetzle, J. Am. Chem. Soc. 1977, 99, 3872.

17. (a) J. C. Slater, Quantum Theory of Molecules and Solids, the Self-Consistent Field of Molecules and Solids, Vol. 4, McGraw-Hill, New York (1974); (b) K. H. Johnson and F. C. Smith, Phys. Rev. B 1972, 5, 831; (c) K. H. Johnson, Adv. Quantum Chem. 1973, 7, 143; (d) K. H. Johnson, Annu. Rev. Phys. Chem. 1975, 25, 39; (e) D. A. Case, Annu. Rev. Phys. Chem. $1982,33,151$.

18. J. H. Wood and M. A. Boring, Phys. Rev. B 1978, 18, 2701.

19. F. A. Cotton, J. L. Hubbard, D. L. Lichtenberger and I. Shim, J. Am. Chem. Soc. 1982, 104, 679.

20. P. Pyykko and J.-P. Desclaux, Acc. Chem. Res. 1979, 12, 276.

21. A. Dedieu, T. A. Albright and R. Hoffmann, J. Am. Chem. Soc. 1979, 101, 3141.

22. E. T. Maas and R. E. McCarley, Inorg. Chem. 1973, 12, 1096.

23. F. A. Cotton, L. R. Falvello and R. C. Najjar, Inorg. Chem. 1983, 22, 375.

24. (a) J. L. Templeton, W. C. Dorman, J. C. Clardy and R. E. McCarley, Inorg. Chem. 1978, 17, 1263; (b) F.
A. Cotton and R. C. Najjar, Inorg. Chem. 1981, 20, 2716.

25. M. D. Curtis, L. Messerie, N. A. Fotinos and R. F. Gerlach, Reactivity of Metal-Metal Bonds, ACS Symposium Series No. 155, Chap. 12. American Chemical Society, Washington D.C. (1981).

26. (a) M. H. Chisholm, Transition Met. Chem. 1978, 3, 321; (b) M. H. Chisholm, C. C. Kirkpatrick and J. C. Huffman, Inorg. Chem. 1981, 20, 871.

27. (a) M. L. Luetkens, Jr, J. C. Huffman and A. P. Sattelberger, J. Am. Chem. Soc. 1983, 105, 4474; (b) M. L. Luetkens, Jr, Ph.D. thesis, The University of Michigan (1984).

28. F. A. Cotton, M. P. Diebold and W. J. Roth, J. Am. Chem. Soc. 1986, 108, 3538.

29. J. C. Huffman, L. N. Lewis and K. G. Caulton, Inorg. Chem. 1980, 19, 2755.

30. K. Schwartz, Phys. Rev. B 1972, 5, 2466.

31. J. C. Slater, Int. J. Quantum Chem. Symp. 1973, 7, 533.

32. K. Schwartz, Theor. Chim. Acta 1974, 34, 225.

33. F. Herman and S. Skillman, Atomic Structure Calculations. Prentice-Hall, Englewood Cliffs, NJ (1963).

34. (a) J. G. Norman, Jr, J. Chem. Phys. 1974, 61, 4630; (b) J. G. Norman, Jr, Mol. Phys. 1976, 31, 1191. 